\title{
Late Carboniferous colonial Rugosa (Anthozoa) from Alaska
}

\section{J. FEDOROWSKI ${ }^{1}$ and C.H. STEVENS ${ }^{2}$}

'Institute of Geology, Adam Mickiewicz University

Maków Polnych 16, PL-61-606, Poznań, Poland.

E-mail: jerzy@amu.edu.pl

2 Department of Geology, San José University

San José, California 95192, USA. E-mail: calvin.stevens@sjsu.edu

\begin{abstract}
Late Carboniferous colonial corals from the Moscovian Saginaw Bay Formation and the underlying Bashkirian crinoidal limestone exposed on northeastern Kuiu Island and a nearby islet, part of the Alexander terrane in southeastern Alaska, are described and illustrated for the first time, and are supplemented by revision, redescription and reillustration of most Atokan specimens from Brooks Range, northern Alaska, first described by Armstrong (1972). New taxa from the Kuiu Island area include the new species Paraheritschioides katvalae and the new genus and species Arctistrotion variabilis, as well as the new Subfamily Arctistrotioninae. The corals Corwenia jagoensis and Lithostrotionella wahooensis of Armstrong (1972) also are redefined and redescribed. Paraheritschioides jagoensis is based on the holotype of ' $C$ '. jagoensis. $P$. compositus sp. nov. is based on a "paratype" of ' $C$.' jagoensis. In addition to a redefinition and redescription of 'L.' wahooensis as Arctistrotion wahooense, one "paratype" of that species is described as A. simplex sp. nov. The phylogeny and suspected relationships of some fasciculate Carboniferous Rugosa also are discussed. Based on relationships and similarities within the Late Carboniferous colonial Rugosa from the Brooks Range, Kuiu Island and the eastern Klamath terrane, we conclude that all three areas were geographically close enough at that time so that larvae were occasionally dispersed by oceanic currents. Distances between these areas, however, may have been so great and/or isolation so long that individual speciation occurred in all of the various locations. That hypothetical situation is reflected by a common generic, but not a specific, content of the particular faunas.
\end{abstract}

KEYWORDS

Colonial Rugosa (Anthozoa). Late Carboniferous. Alaska. Phylogeny. Palaeogeography.

\section{INTRODUCTION}

Corals described here belong to the Subfamily Heritschioidinae Sando, 1985, of the Family Aulophyllidae Dybowski, 1873, to the Family Kleopatrinidae Fedorowski, Bamber, and Stevens, 2007, and the herein newly described Subfamily Arctistrotionae of the Family Lithostrotionidae. Members of the Subfamily Heritschioidinae from the Kuiu Island area and one new species of Heritschioides from the
Brooks Range, considered by Armstrong (1972) a member of his new species Corwenia jagoensis, already have been described in a separate paper (Fedorowski et al., 2014b). In the present paper, the remaining specimens from the Kuiu Island area, some collected by Erik Katvala and others by A.F. Buddington and L.J.P. Muffler, are described and illustrated. Also, most specimens from Armstrong's (1972) collection, not treated in the previous paper, are revised and some are re-described and re-illustrated. We consider a 
revision of Armstrong's species necessary for three reasons: i) The Brooks Range fauna is more diverse than considered by Armstrong (1972). His new species Corwenia jagoensis comprises two or three different genera and his new species Lithostrotionella wahooensis comprises two or three different species and possibly two different genera. ii) His identifications do not fit modern taxonomy and should be corrected for both phylogenetic and palaeogeographical considerations. iii) There are several mistakes in specimen numbers that require corrections. All of these facts have resulted in a misleading recording of the faunal diversity of the Atokan (late Bashkirian) part of the Wahoo Limestone. Those problems in the original paper also have precluded a reasonable palaeobiogeographic reconstruction based on rugose coral distribution during late Bashkirian and Moscovian time, including the possible communication between the Brooks Range and the Alexander terrane in Alaska and the Eastern Klamath terrane in California. In addition, the phylogeny within some lineages of Carboniferous colonial rugose corals was obscured.

Most of the material from both the Brooks Range and Kuiu Island consists of a single or rarely just a few fragments of single colonies for each species. Thus, intraspecific variability could not be included in our descriptions. Difficulty in collecting in these remote areas in Alaska has left us two options: to leave the material alone or to describe and redescribe it despite its being sparse. Here we selected the second option because of the value of those coral faunas both for the phylogeny and paleogeography of Late Carboniferous rugose corals. These subjects are discussed in detail in the Considerations chapter.

The genus Heritschioides Yabe, 1950, present in all three areas mentioned above, has not been documented outside of North America. The genus Paraheritschioides Sando, 1985, however, may appear cosmopolitan after several fasciculate colonies displaying a morphology similar to $P$. grandis Sando, 1985 are revised.

The content and taxonomy of 'Lithostrotionella' wahooensis Armstrong, 1972 in the interpretation of that author is discussed later in remarks concerning the new Subfamily Arctistrotioninae and new genus Arctistrotion. Similar to Paraheritschioides, the Subfamily Arctistrotioninae may also be common to Iran (Minatoa Flügel, 1994) on the northern Gondwana shelves to the southeast and Novaya Zemlja (Lonsdaleia (Wentzelella) diversa, Gorsky, 1938, L.(W.) multivesiculosa Gorsky, 1938 and Lonsdaleia longiseptata Gorsky, 1951) of the Siberian protocontinent.

In the description of fasciculate species the smallest diameters (d) in millimeters as seen in transverse section were measured, whereas both the smallest and longest diameters were measured in the cerioid-aphroid species in which individual corallites commonly are elongated. The number (n) of major septa was counted in both kinds of colonies. These measurements are recorded as $\mathrm{n}$ :d values. Following Hudson (1936) and Fedorowski (1997), only the cardinal and counter major septa are considered protosepta.

\section{Material and Methods}

Samples from three localities in the Kuiu Island area were available for study. United States Geological Survey localities are indicated by numbers followed by the letters PC (e.g. USGS 27727-PC). Localities of Erik Katvala are indicated by a combination of letters and numbers. The geographic position of localities is shown on Figure 1. Detailed descriptions of localities and their stratigraphic positions were published in the first of two papers devoted to colonial corals from Alaska (Fedorowski et al., 2014b) and are not repeated here. Thin sections of all figured specimens have been assigned the letter $\mathrm{C}$ followed by the number of that slide. Slides of all holotypes are housed in the collections of the National Museum of Natural History and bear a USNM number as well as a $\mathrm{C}$ number. Paratypes, other figured specimens, and other samples collected by Katvala, many containing solitary corals, have been placed in the collections of the University of California Museum of Paleontology at Berkeley. All specimens have undergone various diagenetic alterations: compression, replacement by dolomite and/or silica, recrystallization, and dissolution. Those alterations are irregularly distributed within colonies, leaving some corallites or parts of them preserved well enough for photography of the microstructure of septa and for preparation of series of peels elucidating the blastogeny. Some of those series were photographed and drawn using a computer method.

\section{Geological and Geographical Setting}

The corals considered here were collected from two areas in Alaska: the Kuiu Island area (Fig. 1A), the stratigraphy of which is shown in Figure 2, and the Brooks Range. Information on the location and age of the corals from the Brooks Range are given in Armstrong (1972). The locations of samples from the Kuiu Island area are shown in Figure 1B. Descriptions of the localities and ages of the samples in the Kuiu Island are given in occurrences of particular species.

The only other known coral fauna in North America comparable to those in Alaska are in the Eastern Klamath terrane in northern California (Fig. 1B). Information on the location and age of samples from that area are included in the paper by Kawamura and Stevens (2012), in which the colonial corals are described and illustrated. The faunas from all three areas considered are comparable in age (i.e. Bashkirian to Moscovian). 

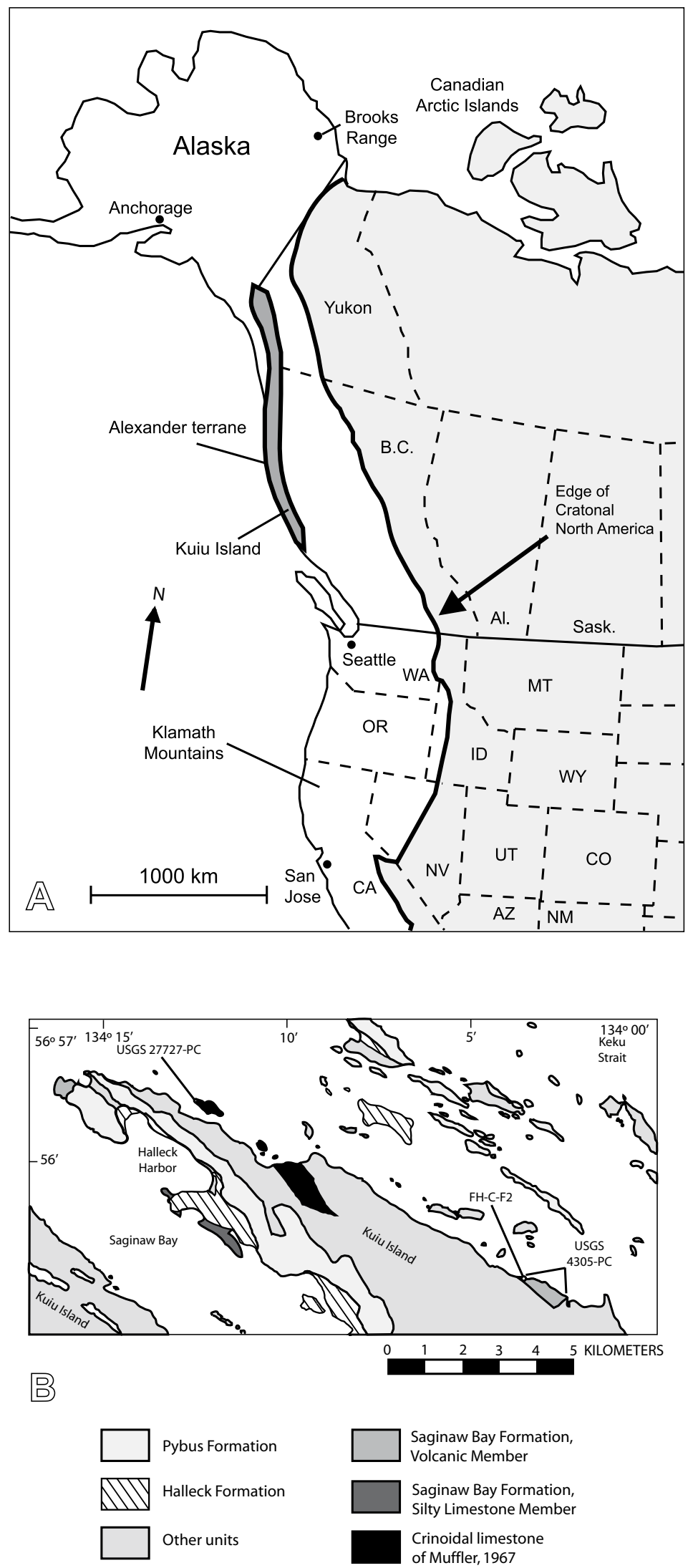

FIGURE 1. Locations. A) Location of Kuiu Island and coral locality in the Brooks Range in northeastern Alaska the eastern Klamath terrane in California. B) Location of sampled localities on Kuiu Island and nearby islets plotted on a geologic map of the area (modified from Fedorowski et al., 2014b). 


\section{SYSTEMATIC PALAEONTOLOGY}

\author{
Class: Anthozoa \\ Subclass: Rugosa MiLnE Edwards and Haime, \\ 1850 \\ Order: Stauriida VERRILL, 1865
}

Family: Kleopatrinidae FEDOROWSKI, BAMBER and STEVENS, 2007

\section{GENUS Paraheritschioides SANDO, 1985}

Type species. Paraheritschioides grandis SANDO, 1985

Diagnosis. Fasciculate Kleopatrinidae with axial structure that may disappear over short intervals of growth; discontinuous axial column within axial structure variably developed, complex in some species; median lamella closely connected to counter septum; cardinal septum variable, not shortened in some corallites; dissepiments locally lonsdaleoid; tabularium indistinctly biform (after Fedorowski et al. 2007, p. 95, emended).

Discussion. Emendation of the generic diagnosis of Paraheritschioides allows inclusion of species with short interruptions in the axial structure, a complex and rarely discontinuous axial column, and a cardinal septum of variable length. Two of those characters are recognizable in rare corallites in the type species for the genus (Sando 1985, fig. 2). The irregularity and interruptions in the axial structure places Paraheritschioides close to the morphologically most advanced species of Heintzella. The most advanced species of Paraheritschioides, i.e. colonies composed mostly of corallites with an almost continuous axial column, approach Wilsonastraea Stevens and Rycerski, 1989.

The morphology of very young offsets, a main criterion for distinguishing between colonial genera of such families as the Aulophyllidae Dybowski, 1873; Durhaminidae Minato and Kato, 1965; Kleopatrinidae Fedorowski, Bamber and Stevens, 2007 and Lithostrotionidae, was established by Fedorowski et al. (2007). We continue to maintain that position. This criterion is especially important for distinguishing between Corwenia and Paraheritschioides. Thus, either the complete blastogeny or an investigation of early growth stages of offsets in random thin sections is described for each species here included in Paraheritschioides (see final Considerations for a more comprehensive discussion).

\section{Paraheritschioides jagoensis (ARMSTRONG, 1972)} Figure 3

e.p. 1972. Corwenia jagoensis ARMSTRONG, p. 10, pl. 1, figs $1-6$; pl. 2, fig. 3 only.

\begin{tabular}{|c|c|c|}
\hline Period & Age & Formation \\
\hline \multirow{2}{*}{ Permian } & Asselian & Pybus Formation \\
\cline { 2 - 3 } & & Halleck Formation \\
\multirow{2}{*}{ Pennsylvanian } & Moscovian & Saginaw Bay Formation \\
\cline { 2 - 3 } & Bashkirian & crinoidal limestone \\
\hline \multirow{2}{*}{ Mississippian } & Serpukhovian & Cannery Formation \\
\hline
\end{tabular}

FIGURE 2. Local Late Paleozoic stratigraphy of the Kuiu Island area (modified from Fedorowski et al., 2014b).

e.p.? 2012. Corwenia? jagoensis ARMSTRONG, 1972?; KaWAMURA and SteVEnS, p. 513, fig. 2:10, 11, 14 only.

Material. Holotype: Colony USNM 161034, illustrated by Armstrong (1972) as cited above, but not specimens illustrated by him on pl. 2, figs. 2, 5. Those specimens bear the same number, but they clearly represent a different colony, and are here transferred to the genus Heintzella. The colony illustrated by Armstrong (1972) in pl. 2, fig. 1 and pl. 3, fig. 1, also given the specimen number USNM 160534 (p. 13, second column, first paragraph in Armstrong, 1972), is here transferred to a new species of Paraheritschioides. Two transverse and one longitudinal thin section of the holotype colony were prepared in addition to the thin sections made and illustrated by Armstrong (1972; pl. 1, figs. 1-6; pl. 2, fig. 1; Fig. 3A, B, herein).

Emended diagnosis. Paraheritschioides with n:d values 29-32:16-18mm; free ended major septa $2 / 3$ corallite radius long; most minor septa reach inner margin of dissepimentarium, slightly less than $1 / 3$ corallite radius wide; some interrupted by small lonsdaleoid dissepiments; cardinal septum shortened; axial structure in transverse section free, with long median lamella; in longitudinal section axial structure continuous, with axial column underdeveloped.

Remarks on Armstrong's (1972) paper. Specimens originally included in 'Corwenia' jagoensis Armstrong 1972 were collected at various stratigraphic levels within foraminiferal Zone 21 of Mamet and Mason (1970). Most of them were derived from measured sections, although some were collected elsewhere. All specimens, however, were obtained from strata considered Atokan (Armstrong, 1972, text-fig. 1 and plate captions) and were considered by Armstrong to belong to this single species despite showing greatly differing morphologic characters. Several were illustrated by him. Differences are especially obvious in the specimens attributed to the holotype colony (Armstrong, 1972; pl. 1, figs. 5, 6, and pl. 2, fig. $3 v s$ pl. 2, figs. 2, 5, vs pl. 2, fig. 1 and pl.3, fig. 1). Our study here, supported 

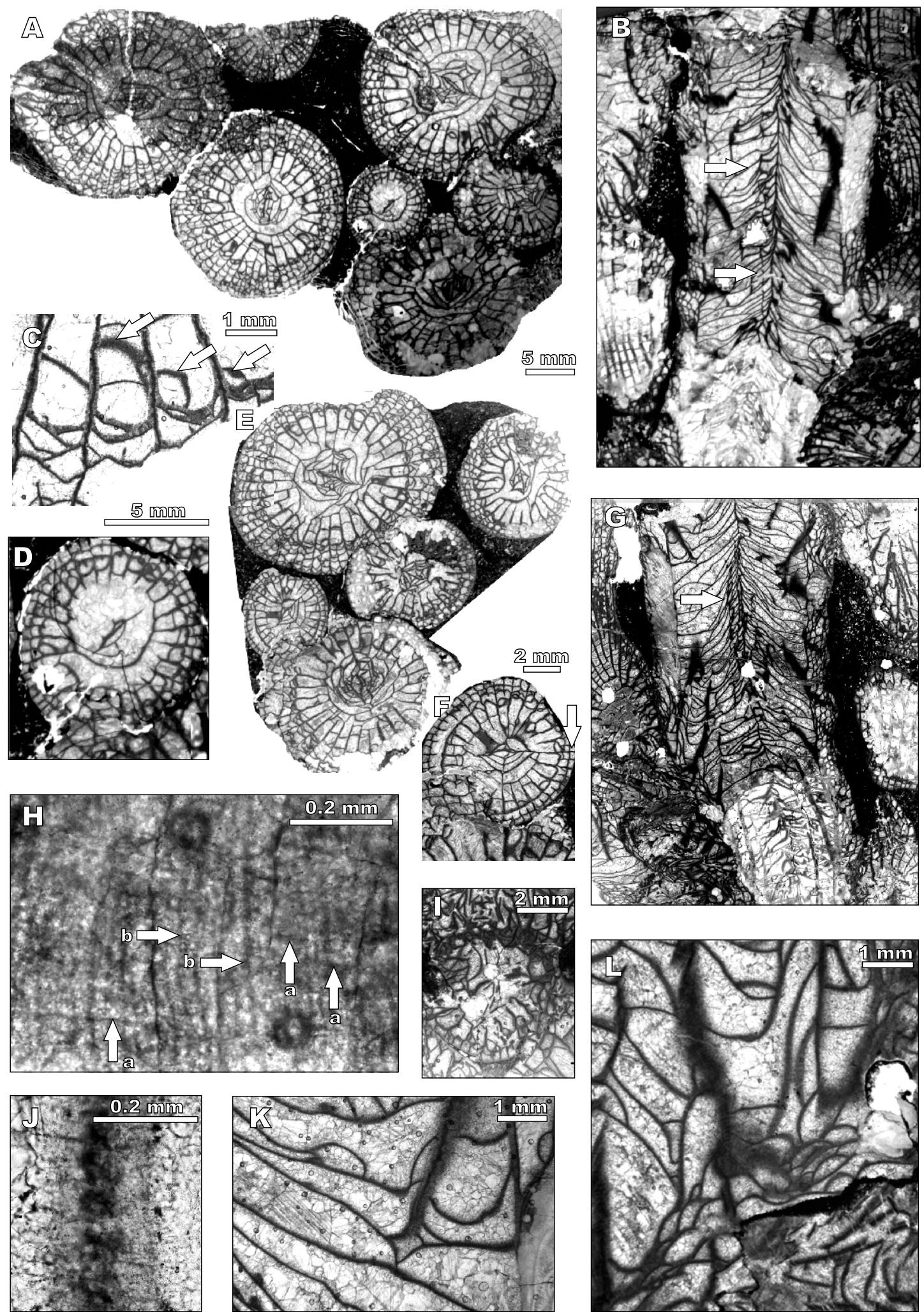

FIGURE 3. Paraheritschioides jagoensis (Armstrong, 1972). Specimen USNM 161034. Holotype. A, E) Successive transverse sections (A from Armstrong, 1972; pl. 1, fig. 6); B, G) successive longitudinal sections (G from Armstrong, 1972, pl. 1, fig. 5); B) arrows point to sections of septal lamellae and G) peripheral tabellae; C) biform arrangement of peripheral parts of tabulae (arrows; enlarged from 3E); D, F) immature corallites (enlarged from 3A, E, respectively; counter septum in F pointed by arrow); I) offset connected to adult corallite by partition (arrow); H) remnants of trabeculae (arrows with 'a') and growth lines (arrows with 'b') in longitudinal section; J) remnants of trabeculae in transverse section; K, L) peripheral biform tabularium (enlarged from 3G). Magnification of each figure shown by bar. 
by new thin sections, allows the following conclusions: i) Fragments of three different colonies belonging to three different species were erroneously considered to belong to the holotype colony of Corwenia jagoensis by Armstrong (1972). The first illustrated fragment (Armstrong, 1972; pl. 1, figs. 5, 6, pl. 2, fig. 3; Fig. 3A-L herein) is by the International Commission on Zoological Nomenclature (ICZN) rules considered the true holotype. It is here renamed Paraheritschioides jagoensis (Armstrong, 1972) and is redescribed below and reillustrated. ii) The second part of the 'holotype' colony (Armstrong, 1972; pl. 2, fig. 1, and pl. 3, fig. 1) differs greatly from the true holotype in its morphology, corallite diameter, number of septa, axial structure, width of dissepimentarium, length of minor septa, and state of preservation. The state of preservation and diameter of the longitudinal section ( $\mathrm{pl}$. 2, fig. 1) closely correspond to that of a transverse section (pl. 3, fig. 1) which Armstrong (1972; p. 13) assigned the number USNM 160534. Thus, we consider both figures as belonging to the same specimen which is different from the holotype. That coral also corresponds to Armstrong's (1972) paratype USNM 161039 (pl. 4, figs. 2 and 4, incorrectly indicated as figs. 2 and 3 in the caption, and Figs. 4A-F; 5A-G herein). On the basis of that 'paratype', these specimens are described below as Paraheritschioides compositus sp. nov. iii) The morphology in transverse sections of both the mature and immature corallites and the longitudinal section (Armstrong, 1972; p. 2, figs. 2, 5), also attributed by Armstrong to the holotype of $C$. jagoensis, differs considerably from that of both the true holotype and the specimen discussed in the previous paragraph. The axial structure in the mature corallites is weak, irregular and interrupted. It closely resembles Heintzella Fedorowski (1965, text-figs. 10a, 11, 13), identified as Fischerina Stuckenberg, 1904 at that time and later transferred (Fedorowski, 1967 ) to the latter genus. Thus, we consider that sample different from the holotype and provisionally assign it to the genus Heintzella.

USNM 161040 is considered to belong to the genus Heritschioides Yabe, 1950, and has been removed from 'C.' jagoensis and given a new specific name (Fedorowski et al., 2014b). In transverse sections, the 'paratype' colony USNM 161038 of 'C.' jagoensis Armstrong, 1972; pl., 3, figs. 3, 4 resembles Corwenia vaga Smith and Ryder, 1926 in possessing a thin median lamella, which intersects the entire axial structure and is elongated towards the cardinal septum in most corallites, and an axial structure isolated from the inner margins of the major septa. In the longitudinal thin section (Armstrong, 1972; pl. 3, fig. 2) the lack of an axial column in the lower part of that corallite probably has resulted from diagenetic alteration. The upper part of that corallite shows a peculiar axial column similar to that of Corwenia, if the concept of that genus is broadened to include corallites with major septa withdrawn from the axial structure and the cardinal septum only slightly shortened or equal to adjacent major septa, as shown by $C$. vaga. These features, however are not shown in the type species, C. rugosa (McCoy, 1849). The differences mentioned here are expanded upon in the final Considerations chapter. Poor preservation of the colony and lack of early growth stages prevents a confident identification of specimen USNM 161038.

Specimen USNM160537, illustrated by Armstrong (1972) in pl. 4, fig. 1, was not available for study. However, the connection of the median lamella to the cardinal septum and presence of probable extra septal lamellae suggest the genus Heritschioides. Thus, because of their great morphologic differences, none of Armstrong's paratypes are here considered to belong to ' $C$.' jagoensis.

Emended description. Holotype colony consists of both almost complete corallites and crushed branches between those corallites, as best shown in longitudinal sections (Fig. $3 \mathrm{~B}, \mathrm{G})$. Major septa in mature corallites slightly thickened in tabularium, terminated far short of axial structure (Fig. 3A, E, mature corallites). Cardinal septum slightly shortened, in open cardinal fossula that narrows adaxially and dips slightly into dissepimentarium. Monoseptal median lamella, commonly united with counter septum, slightly thickened or thin, intersects entire axial structure, may extend towards cardinal septum, but does not meet its inner margin. In addition to median lamella, axial structure composed of three to five short septal lamellae on each side and three to five rings of axial tabellae or tabulae on each side (as seen in transverse sections). In longitudinal sections (Armstrong, 1972; pl. 1, fig. 5; pl. 2, fig. 3; Fig. 3B, G, herein) well isolated axial column very poorly developed. Rings of suspected axial tabellae seen in transverse section are inner margins of densely packed, incomplete tabulae, very steeply elevated towards continuous median lamella. Sections of septal lamellae imitate lateral tabellae of axial structure in some parts of sections (Fig. 3B, arrow), but axial tabellae and rare lateral tabellae also may be present (Fig. 3G, arrow). Tabulae mostly incomplete, steeply elevated towards median lamella near corallite axis with 1-3 additional lamellae attached to individual tabulae in some cases. Globose, horizontal and sagging peripheral tabellae (Fig. 3K, L) are sections of biform tabulae (see Sutherland, 1965), not clinotabellae as confirmed by separation of tabula into its two positions. This appears next to inner margin of septum (Fig. 3K). Biformity of the tabularium also confirmed by positions of peripheral parts of several tabulae in transverse section (Fig. 3C, arrows). Minor septa mostly continuous, rarely interrupted by small lonsdaleoid dissepiments, intersect entire dissepimentarium when continuous, do not penetrate tabularium. Very long peripheral break of both major and minor septa (Fig. 3F) illustrates an early stage 

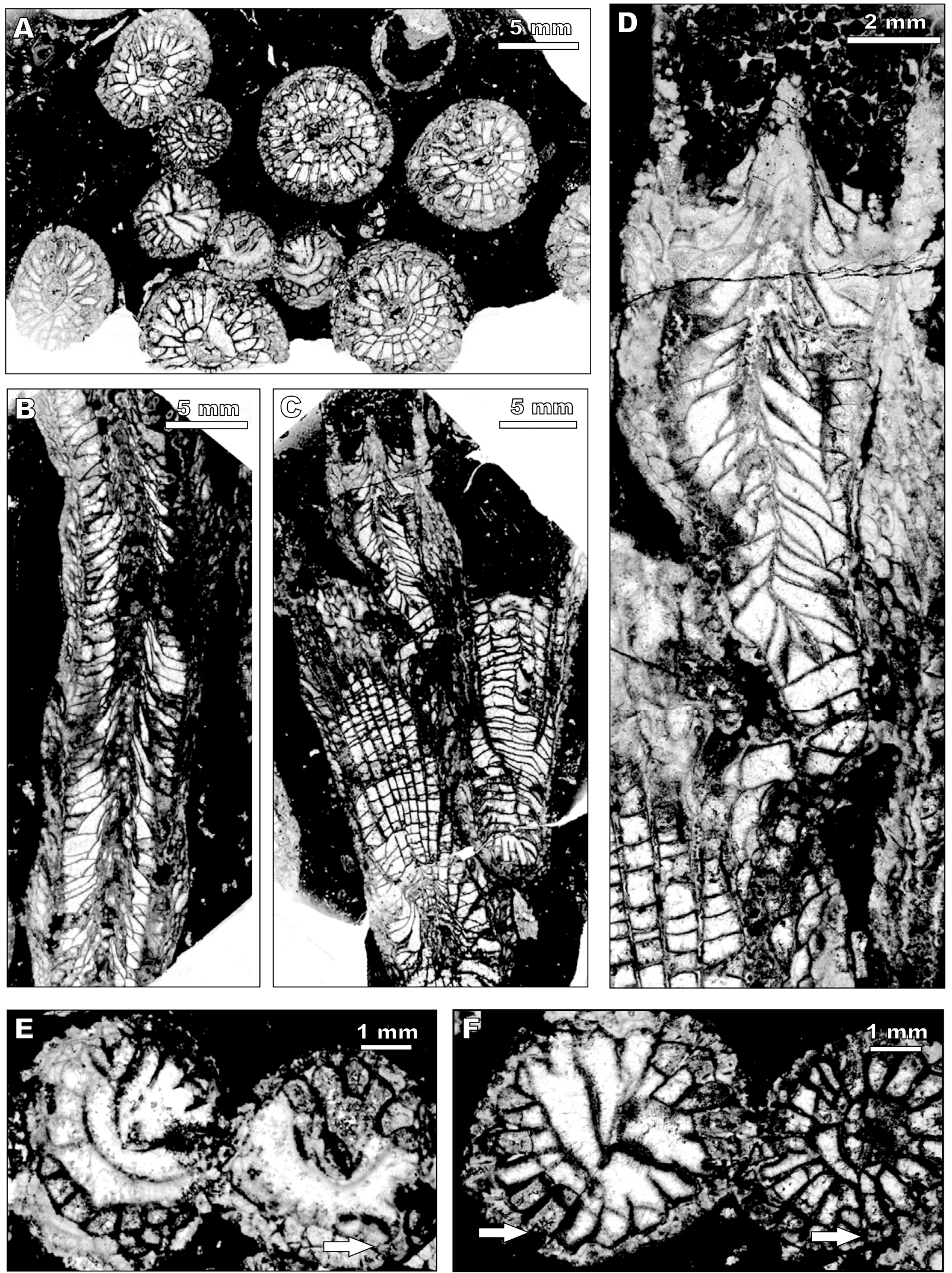

FIGURE 4. Paraheritschioides compositus sp. nov. Specimen USNM 161039. Holotype. A, E, F) Transverse sections; A) fragment of colony; E, F) immature corallites (enlarged from A; cardinal septa indicated by arrows); B-D) longitudinal sections; B) well oriented section of mature corallite C) oblique mature and well oriented immature corallites; D) immature corallite showing lack of axial structure early in blastogeny and increasing complexity with corallite growth. Magnification of each figure shown by bar. 
of rejuvenation. Dissepimentarium occupies slightly more than $1 / 4$ corallite radius; composed of five to eight rows of very steeply dipping, mostly regular, globose dissepiments (Fig. 3B, G). Tabularium normal in some, biform in other septal loculi as shown both by arrangement of peripheral parts of tabulae in transverse section (Fig. 3C, arrows) and in longitudinal section (Fig. 3K, L).

Detailed study of blastogeny hindered by paucity of material available. At early growth stage, partly crushed offset isolated from parent by partition (Fig. 3I) lacks axial structure and has all major septa free ended, none reaching corallite axis. Long-lasting connection of parent's and offset's bodies typical for genus. Blastogenetically more advanced offset (Fig. 3D, enlarged from 3A) has short, thin major septa, some interrupted minor septa, and long free median lamella, with three very short septal lamellae attached. More advanced growth stage of offset (Fig. $3 \mathrm{~F}$, enlarged from $3 \mathrm{E}$ ) characterized by counter septum (arrow) continuous into thin septal lamella extending almost to cardinal septum, and by elongated alar septa that approach median lamella. Few sections of axial tabulae imitate axial tabellae similar to mature corallites. Many discontinuous septa suggest rejuvenation, as mentioned above. Morphology of small corallite shown in transverse section (Fig. 3E) intermediate between fully mature and early corallite shown in Figure 3A, D.

Microstructure of holotype strongly but irregularly altered by diagenesis including compression, recrystallization and replacement. Compression resulted in both crushed inner skeletal structures of corallites (Fig. 3B, G, I, L) and penetration of one corallite into one or two adjacent ones (Fig. 3A, E, F). Replacement of two kinds: by silica (Fig. 3B) lower part in longitudinal section and left incomplete corallite (Fig. 3G), and by dolomite (Fig. 3A, grayish upper 3/4 of left uppermost corallite). Recrystallization most obvious in microstructure of septa (Fig. 3H, J). However, isolated bunches of black crystalline fibrils in transverse section of primary septum (Fig. 3J) and indications of bodies perpendicular to growth layers (Fig. 3H, arrows with 'a') suggest finely trabecular microstructure with individual trabeculae narrower than $0.01 \mathrm{~mm}$, but with exact width unknown.

Discussion. The present species differs from the type species of the genus and from all other Late Carboniferous species of Paraheritschioides in Alaska, including specimen USNM 161034, described by Armstrong (1972) as part of the holotype colony (see above), in its larger diameter and number of septa, its wider dissepimentarium consisting mainly of rectangular dissepiments, and the underdevelopment (or absence) of an axial column within the axial structure. The present redescription of the blastogeny, microstructure and intraspecific variability is incomplete because this sample consists of only small remnants of a colony.

Kawamura and Stevens (2012) investigated several isolated corallites from the early Atokan Baird Formation (Fm.) (Klamath Mountains, California, USA) and described them as Corwenia? jagoensis, despite doubts expressed by them as to both the generic and specific relationships of their specimens to the Brooks Range colonies. They divided their specimens into two morphotypes corresponding to Armstrong's (1972) illustrations of the 'holotype' of $C$. jagoensis as follows: their morphotype 1 corresponds with Armstrong's plates 1 and 2, and their morphotype 2 to his plate 3 , figure 1 . In the senior author's opinion, different morphotypes of geographically distant specimens cannot correspond to particular parts of a single holotype colony. Such an approach indirectly suggests different genotypes of those parts. However, a mistake made by Armstrong by placing different colonies into the holotype of $C$. jagoensis justifies the distinction proposed by Kawamura and Stevens (2012). These morphotypes represent different specimens and species, not different parts of the same colony. We questionably include morphotype 1 of Kawamura and Stevens (2012) in Paraheritschioides jagoensis, but we base this exclusively on several similarities between the two groups of corals. Those similarities may not mean a true genetic relationship.

Occurrence and Age. Brooks Range, Alaska, "250 feet below the top of East Sadlerochit Mountains section 68A-4A-4B, Wahoo Limestone, Atokan age" (Armstrong, 1972; captions to pl. 1). ?Klamath Mountains, NW California, Baird Fm., early Atokan (Bashkirian).

\section{Paraheritschioides compositus sp. nov.}

Figures 4, 5

e.p. 1972. Corwenia jagoensis ARMSTRONG, p. 10, pl. 2, fig. 1, pl. 3, fig. 1, pl. 4, figs 2, 4 only.

\section{Holotype. Specimen USNM 161039.}

Type locality. "230 feet below the top of the Egaksrak River section 68A-5" (Armstrong, 1972; caption to plate 4).

Type stratum. Wahoo Limestone.

Etymology. Latin compositus, a, um (compound, collated) after being revised and including both a paratype and a colony considered by Armstrong (1972) as part of the holotype of "Corwenia” jagoensis.

Diagnosis. Paraheritschioides with $\mathrm{n}: \mathrm{d}$ values $23: 8 \mathrm{~mm}$ to $25: 9.5 \mathrm{~mm}$; major septa approach and some incorporated into axial structure; most minor septa restricted to 

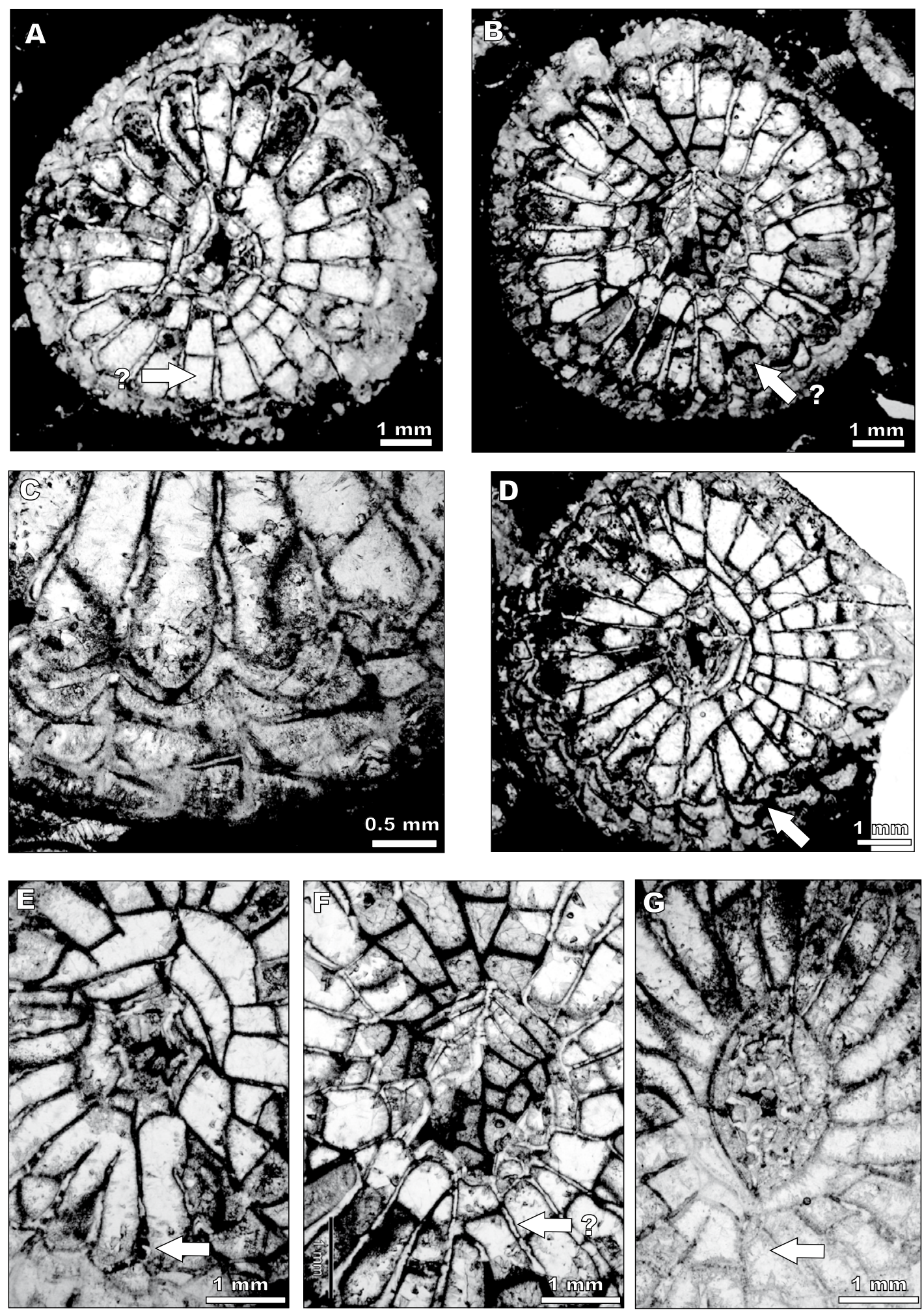

FIGURE 5. Paraheritschioides compositus sp. nov. Specimen USNM 161039. Holotype. Transverse sections; A, B, D) mature corallites showing various morphology of axial structure and position of suspected (arrows with '?') cardinal septa; large parts of dissepimentaria replaced by silica; C) reasonably well preserved dissepimentarium and minor septa differentiated in length (enlarged from D, left side); E, F) simple narrow and complex wide axial structure ( $F$ enlarged from B); G) altered axial structure surrounded by sections of tabulae with inner margin of counter septum extended to corallite axis. Magnification of each figure shown by bar. 
peripheral part of dissepimentarium that occupies less than 1/4 corallite diameter; cardinal septum almost indistinguishable from other major septa by length, rarely shortened; counter septum generally, and cardinal septum less commonly, connected to long median lamella; complex axial structure forms axial column in mature corallites.

Material. The holotype colony, consisting of five small fragments, was restudied. A specimen illustrated by Armstrong (1972; pl.2, fig. 1; pl. 3, fig. 1) as part of holotype (not found in the original collection, but probably belonging to specimen USNM 160534), was included in this species on the basis of Armstrong's illustrations. In addition, four transverse and three longitudinal thin sections and ten peels, all from the holotype, were available for study. Interior morphology of some corallites destroyed by diagenesis. Microstructure of septa not preserved.

Description. Most common number of septa in holotype corallites 23 at $8.0,8.5,8.8$ and $9.5 \mathrm{~mm}$ in diameter. Other measured $\mathrm{n}: \mathrm{d}$ values are $21: 8.0 \mathrm{~mm}, 22: 8.3 \mathrm{~mm}$, 24:8.0mm, 25:9.0mm. In mature specimens major septa slightly thickened at tabularium boundary, vary in length and arrangement. Thin inner margins of most approach axial structure, some reach it and/or are incorporated into it; some shortened and either free or attached to adjacent major septa (Figs. 4A, 5A, B, D-G). Protosepta almost indistinguishable from adjacent major septa and from each other in most corallites. Cardinal septum rarely slightly shortened (Fig. 5D, lower). Counter septum permanently connected to median lamella. Cardinal fossula absent. Minor septa vary in length, most restricted to peripheral dissepimentarium, some reach its inner margin, but none penetrates tabularium (Fig. 5A-D). Axial structure in mature corallites variable in width and composition, connected to some or most major septa (Fig. 5A, B, D-G), consists of thin median lamella, few septal lamellae and/ or inner margins of major septa, and several very steeply inclined axial tabellae (Fig. 4B, C, D upper) to form distinct axial column. Tabularium consists of mostly complete tabulae, gently elevated towards axial column. Dissepimentarium composed of small herringbone and pseudoherringbone dissepiments in two to three rows arranged at approximately $45^{\circ}$ to external wall.

Immature corallites (Fig. 4A, E, F) possess short major septa equal in length except for elongated counter septum in all corallites observed; cardinal septum (Fig. $4 \mathrm{E}, \mathrm{F}$, arrows when recognizable) either free or connected to median lamella. Counter septum united with median lamella, except when diagenetically damaged (Fig. 4E, left corallite). Well oriented longitudinal section exhibits offset's morphology from earliest growth stage (Fig. 4C, D) and confirms lack of axial structure at that growth stage and its restriction to median lamella during initial phase of independent offset's growth, thus corresponding to transverse sections described above. Axial structure continuous becoming increasingly more complex up to formation of axial column elevated high above calice floor.

Advanced diagenetic alterations preclude microstructural and blastogenetic studies. Peripheral parts of corallites almost completely silicified as are parts of axial structures in most corallites (Fig. 5A, B, D-F). One almost completely destroyed (Fig. 5G) with surrounding sections of tabulae imitating lens-shape pendulum.

Discussion. This species and the type species of the genus are similar in their $\mathrm{n}$ :d values and possession of narrow dissepimentaria, but differ in that the new species possesses a cardinal septum barely distinguishable by length, major septa that closely approach the axial structure, minor septa reduced in length, and most important, an almost continuous axial column in the axial structure. The latter character distinguishes it from all other species of Paraheritschioides described so far, including P. katvalae sp. nov., another species displaying a barely distinguishable cardinal septum and a narrow dissepimentarium. From $P$. jagoensis, into which the holotype and the paratype of this species were included by Armstrong (1972) (see above), it differs in having much smaller corallite diameters and numbers of septa, major septa which approach the axial structure, minor septa restricted to periphery of narrow dissepimentarium and an almost continuous axial column in the axial structure.

Occurrence and Age. "230 feet below the top of Egaksrak River section, 68A-5” (Armstrong, 1972; captions to plate 4, figures 2, 4; not 2, 3 as written by Armstrong). Early Atokan (Bashkirian in age).

\section{Paraheritschioides katvalae sp. nov.}

Figures 6, 7

Holotype. USNM 545247 = sample FH-C-F2\#2.

Type locality. Cornwallis Peninsula, Kuiu Island, Alaska

Type horizon. Volcanic Member of Saginaw Bay Fm.

Name derivation: Named in honour of Erik Katvala who collected the holotype of this species and provided other material for this study.

Material. Holotype specimen listed above from which four transverse, seven longitudinal thin sections and 22 peels have been made; paratype, sample 4305-PC \#1, with one transverse section. Corallite peripheral parts in all samples silicified. Some corallites crushed or partly 
dissolved. Internal structures of most corallites within holotype colony well preserved.

Diagnosis. Paraheritschioides with n:d values 18:6.5mm to $21: 7.0 \mathrm{~mm}$; some major septa may penetrate variable, rarely interrupted axial structure, in part an axial column; most minor septa intersect dissepimentarium, consisting of 1-2 rows of dissepiments, locally discontinuous; cardinal septum not shortened in most.

Description. Corallum fasciculate. Corallites closely packed (Fig. 6A, F-H). External wall less than $0.1 \mathrm{~mm}$ thick. Maximum corallite diameter $7.5 \mathrm{~mm}$. Selected n:d values: $18: 6.5 \mathrm{~mm}, 19: 6.3 \mathrm{~mm}, 20: 6.0,6.5,7.0,7.5 \mathrm{~mm}$, 21:6.0, 7.0mm. Most common n:d value 20:7.0mm. Major septa thin, variable in length, some penetrate axial structure. Counter septum locally continuous with median lamella. Cardinal septum variable in length, in some corallites connected to median lamella, in others equal to other major septa or slightly shortened. Minor septa very short, most penetrate tabularium. Axial structure seen in transverse sections of mature corallites (Fig. 6A, F-H) composed of locally thickened median lamella and 3-6 septal lamellae and/or inner margins of major septa attached to both sides. Lack of axial structure in rare corallites confirms its lack of continuity. Only elongated counter septum in immature corallites. In longitudinal section (Fig. 6B-E) axial structure ranges from single median lamella to narrow, discontinuous axial column composed of median lamella and steeply dipping axial tabellae. Short temporary interruptions of axial structure confirmed by longitudinal sections (Fig. 6B, C) as well as transverse sections. Dissepimentarium very narrow, locally discontinuous, generally consisting of one rank of small globose interseptal dissepiments. Tabularium composed of complete and incomplete tabulae, about 14/cm, some extending directly to median lamella, others merging into variously arranged axial tabellae forming interrupted axial column. Lateral tabellae rare. Biform morphology in some loculi and normal in others, as suggested by sections of peripheral parts of tabulae.

Blastogeny. Study of blastogeny incomplete in some aspects because: i) Local silicification between sections shown in Figure 7C and D makes that step of development uncertain. Better samples preserving earliest insertion of septa in offset not found. ii) Slightly oblique orientation of offset has resulted in apparent difference in septal increase in left and right halves of the corallite. Right cardinal and counter quadrants appear initially more advanced in development. iii) Length and direction of individual major septa of offset towards its axis changes during early growth. iv) Poor state of preservation precludes recognition of septa inherited from parent corallite, except cardinal septum. v) Additional corallite in Figure 7L strongly dolomitized at periphery, thus mostly left blank on this figure.
Morphology in offsetting sector of parent corallite at first marked by reduction of most minor septa (Fig. 7AC). In specimen investigated in detail, one minor septum first becomes elongated (Fig. 7B, C), later divided into increasingly reduced peripheral and inner sectors; and finally attached to adjacent major septum for a long period before being attached to parent's neoseptum to form its major septum (Fig. 7D-H). Those changes interpreted here as incidental.

Cardinal septum, located at peripheral part of offset, perhaps inherited from parent as indicated by connection to parent's septum (Fig. 7D, E). That connection not interpreted as an axial septum because offset's counter septum appears in different part of offset (compare Fig 7E and 7G). Length of cardinal and all other major septa change several times during hystero-brephic growth stage (Fig. 7D-H). In general cardinal septum remains long. Counter septum, absent from early growth stages (Fig. 7D-F), elongates soon after appearance and stays long, reaching corallite axis at final corallite growth stage studied (Fig. 7G-K, arrow). Cardinal and counter septa do not meet and axial septum lacking. Median lamella constituted from thickened inner margin of counter septum that remains united with it. Right alar septum appears early in hystero-ontogeny (Fig. 7D) and continues to maintain a similar position. Also, in right cardinal quadrant two septa inserted during $0.3 \mathrm{~mm}$ of corallite growth (Fig. 7E) and remain same in number and position until end of blastogeny studied. Insertion of left alar septum apparently preceded by insertion of two major septa in left cardinal quadrant (Fig. 7E-G), resulting from obliqueness of sections. Grinding and peeling oriented perpendicular to parent corallite, but not to offset's curvature in its early growth stage. Arrangement and length of septa becomes normal when sectioned perpendicularly (Fig. 7H-J). Insertion of septa in counter quadrants apparently delayed by comparison to those of cardinal quadrants. Also, for similar reason, i.e. exposition of parts of offset differently advanced in hystero-ontogeny, that insertion displays irregularity similar to that in left cardinal quadrant. Counter septum hidden in bulge of common parent/offset area when major septa of counter quadrants in offset already present (Fig. 7F, arrow). Length of major septa in those quadrants and their positions stabilized only near end of offset's development in corallite available for study (Fig. 7L). Much earlier appearance of dissepiments at offset's periphery (Fig. 7I-L) also apparently resulted from orientation of surface peeled.

Common parent/offset sector remains divided by partition until end of blastogeny available for study. That connection, i.e. complete, perhaps long-lasting contact of both polyp bodies, documented by more developed offset (Fig. 7K) that remains divided from its parent polyp by a partition. That second corallite shows underdevelopment of 
its inner part similar to corallite described in detail. Also, it documents permanent elongation of counter septum and its union with slightly thickened median lamella. Minor septa appear prior to development of dissepimentarium in both corallites as normal in colonial Rugosa.

Discussion. This species differs from the type species, $P$. grandis Sando, 1985 from the Late Carboniferous of Idaho, in smaller n:d values, a narrower dissepimentarium, and more variation in length of major septa, many of which penetrate axial structure. This species bears closest resemblance to $P$. complexa Sando, 1985 also from the Late Carboniferous of Idaho in having similar $\mathrm{n}: \mathrm{d}$ values, a narrow dissepimentarium, which is discontinuous in places, and a cardinal fossula either lacking or very inconspicuous. It should be pointed out that the cardinal septum in several corallites in the type colonies of those three species are either only slightly shortened or equal to adjacent major septa, thus requiring emendation of the generic diagnosis. P. katvalae differs from $P$. complexa in having more variation in length of the major septa, which commonly penetrate the axial structure, a cardinal septum connected to the median lamella in several corallites, minor septa commonly penetrating the tabularium, axial tabellae that hug the axial lamella much more closely, and tabulae more commonly continuous. Corallites of $P$. katvalae have similar corallite diameters and length of major septa, including the cardinal septum, to $P$. compositus sp. nov. from the Atokan (Bashkirian) of the Brooks Range, Alaska, but differ from those in that species in having a smaller number of septa, longer minor septa that commonly intersect a narrow dissepimentarium, and a much simpler axial structure. A weak axial column is rarely developed, whereas in P. compositus the complex and well separated axial column continues for several centimeters of corallite growth. Despite differences listed above and their stratigraphic and geographic differences, all four species form a group of morphologically very similar and perhaps closely related taxa.

Occurrence and Age. Holotype: FH-C-F2, Floating Hatchery, Keku Strait Region, south end of Cornwallis Peninsula on the northeast shore of Kuiu Island. Paratype: USGS 4305-PC. Petersburg 1:4 quadrangle, Kuiu Island, west of south end of Keku Island Group. Moscovian in age.

Suborder: Lithostrotionina SPASSKIY and KACHANOV, 1971

Family: Lithostrotionidae D'ORBIGNY Subfamily: Arctistrotioninae subfam. nov.

Diagnosis. Lithostrotionidae with cerioid and cerioidaphroid colonies; median lamella derived from axial septum or counter septum alone; axial structure, including axial column, may be discontinuous; offsetting lateral; microstructure of septa finely trabecular; incipient biformity of tabularium in some loculi; lonsdaleoid dissepiments present.

Remarks. The peculiar morphology of Arctistrotion gen. nov. described below bears a close resemblance to the Family Lithostrotionidae and some resemblance to the Family Kleopatrinidae Fedorowski, Bamber and Stevens, 2007. In important aspects, however it differs from both. Arctistrotion is morphologically closest and, perhaps, most closely related to the Subfamily Lithostrotioninae. Representatives of that subfamily flourished during the Mississippian up to the early Serpukhovian. They were especially common during the Viséan when they were among the most abundant taxa of the Rugosa and known from all continents, except Australia. However, the Serpukhovian/Bashkirian boundary, the time of greatest crisis in Carboniferous and Permian rugose coral evolution (Vassilyuk, 1974; Fedorowski, 1981), also marked the limit of development of the overwhelming majority of the lithostrotionid taxa. Indisputable members of the Subfamily Lithostrotioninae disappeared before the end of Pendleian (early Serpukhovian, E1 ammonite Biozone). After that time rare representatives, mainly of the Subfamily Diphyphyllinae, continued to develop in Eurasia, North Africa, and North America. The last representatives of that lineage are known only from the Cisuralian of the Cordilleran-Arctic-Uralian Realm (Fedorowski et al., 2007). However, all those remaining taxa are fasciculate forms with very simple morphologies. Cerioid and/or cerioid-aphroid lithostrotionid taxa have been, to our knowledge, only twice recorded from the Pennsylvanian strata of North America. Those occurrences include 'Lithostrotionella' wahooensis Armstrong, 1972 and colonies described by Kawamura and Stevens (2012) as species of the Permian genus Pararchnastraea Stevens and Rycerski, 1989. Those colonies are morphologically close to that Permian durhaminid genus, but a long time gap between the occurrence of these corals, and the complex morphology of the Upper Carboniferous species, which contrasts with the simple Asselian representatives of the Family Durhaminidae, in addition to several different characters in early blastogeny, which were established when the material was studied again by Cal Stevens, suggests they should be included in the Subfamily Arctistrotioninae.

Taxa recorded from Novaya Zemlja (Gorsky, 1938, 1951) and from Eastern Iran (Flügel 1974, 1994) are the only records known to us of Bashkirian cerioid or cerioidaphroid rugose corals outside North America resembling Arctistrotion. Other such species there belong to the Family Petalaxidae Fomichev, 1953. Although possibly related to Arctistrotion, all those taxa need careful revision prior to becoming included in that genus or subfamily. Gorsky's $(1938,1951)$ descriptions of species from the Novaya 


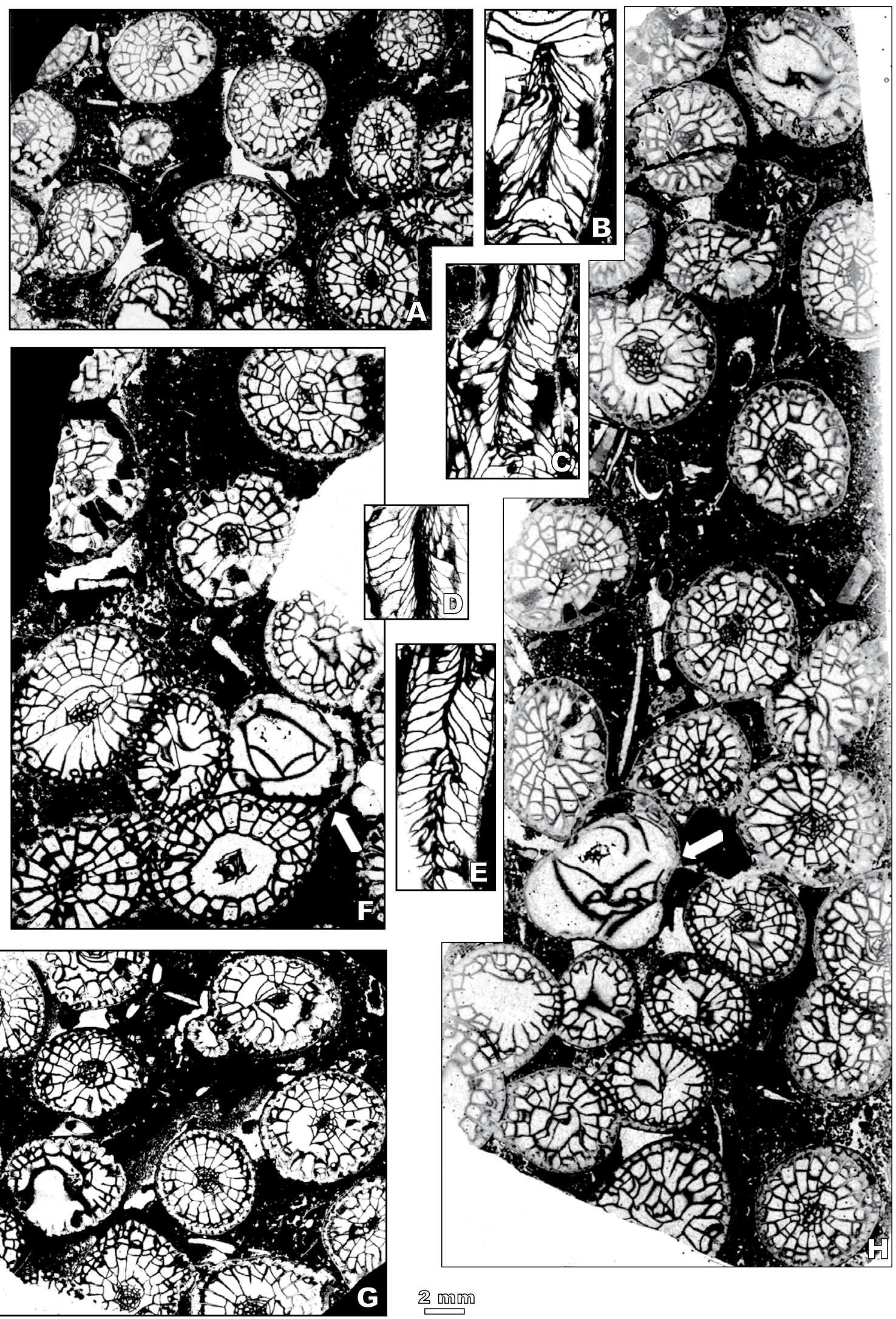

FIGURE 6. Paraheritschioides katvalae sp. nov. Holotype. USNM 545247 = FH-C-F2 \#2. A, F-H) Transverse sections. F and H successive sections, but in a mirror image position. Note peculiar pathologic corallite (arrow); B-E) longitudinal sections. Scale bar between $\mathrm{G}$ and $\mathrm{H}$ corresponds to all images. 
Zemlja lack details in the morphology including the level of the intracolony integration (cerioid vs cerioid aphroid), the blastogeny and the microstructure of septa. In addition, their stratigraphic position is uncertain. The stratigraphic position of the Iranian taxa, both from the Ozbak-Kuh Mts., East Iran, is well established. Minatoa Flügel, 1974 , represented by three species, is accompanied by the conodonts Streptognathodus parvus and Declinognathodus lateralis (Flügel, 1974, p.97), whereas the single colony identified by Flügel (1994) as Kleopatrina (Porfirievella) bashkirica sp. nov. is from the Millerella zone. Unfortunately, the brevity of the descriptions of the Iranian species and the inadequacy of the illustrations, restricted to one transverse and one oblique longitudinal section for each species, do not allow a rigorous comparison to the Alaskan corals at either the specific or generic level. However, these corals resemble Arctistrotion in such important characters as a possible derivation of the median lamella from the axial or counter septum alone and morphology of the axial structure. We consider their relationship to the Alaskan specimens probable.

The main morphological characters of Arctistrotion pointing towards the Lithostrotionidae and to the genus Lithostrotion Fleming, 1828, in particular are: the bilateral symmetry in the arrangement of septa, with the cardinal and counter septa and the median lamella forming the symmetry axis, a median lamella derived from the axial septum or the counter septum alone, the absence of a cardinal fossula, and the rarely observed shortening of the cardinal septum in some corallites.

The morphological similarity of the Arctistrontioninae to the Family Kleopatrinidae is much less obvious. Carboniferous and Permian genera of the latter family, listed by Fedorowski et al. (2007), form a lineage leading from morphologically simple, fasciculate colonies with weak and irregular axial structures and radially arranged major septa, present during Carboniferous time (e.g. Heintzella Fedorowski, 1967), to the morphologically very complex cerioid-aphroid Permian genus Langenheimia Wilson, 1982. Massive kleopatrinid colonies first appear in the early Cisuralian (Asselian) and achieved their acme in the Sakmarian (Fedorowski et al., 2007). Thus, an increasing complexity in both growth form and morphology through time occurred for the Family Kleopatrinidae, whereas simplification would be required if the cerioid-aphroid Bashkirian-Moscovian genus Arctistrotion is included in that family. We cannot accept a reversal in evolution within the same lineage. Instead, a simple solution would be to postulate a short- lasting refuge of an unknown early Serpukhovian species of Lithostrotion in the early Bashkirian, during which new qualitative characters of Arctistrotion were developed. The latest Serpukhovian/ early Bashkirian 'Kleopatrina (Porfirievella)' bashkirica may fill in a gap between the stratigraphically youngest appearance of Lithostrotion noted so far, i.e. Pendleian (lower Serpukhovian, E1 ammonite Biozone) of Morocco (Cózar et al., 2013) and late Bashkirian (Atokan) Arctistrotion from the Brooks Range, if that Iranian species is documented as a member of the latter genus. Thus, we accept a position of Arctistrotion within the Family Lithostrotionidae as achieved in a simple way and reject its relationship to the Permian Kleopatrinidae requiring several undocumented changes.

Characters demonstrated by Arctistrotion, however, differ from the diagnostic features attributed to the Subfamily Lithostrotioninae and other subfamilies of the Family Lithostrotionidae. That difference is large enough (see the family diagnosis above and detailed description of species below) to separate the two groups at a subfamily level with the introduction of the new Subfamily Arctistrotioninae.

\section{GENUS Arctistrotion gen. nov.}

Type species. Arctistrotion variabilis sp. nov.

Name derivation. Combination of first two syllables of Latin arcticus (arctic, after occurrence of its type species), and strotion (after suggested relationship to Lithostrotion Fleming, 1828).

Diagnosis. Cerioid-aphroid Arctistrotioninae; partitions continuous; cardinal septum slightly shortened in some corallites; axial structure generally continuous, but may temporarily disappear from some mature corallites; discontinuous axial column may occur; dissepiments generally interseptal; lonsdaleoid dissepiments rare.

Discussion. Paucity of colonial corals in the Pennsylvanian strata of western hemisphere other than those belonging to the Family Petalaxidae Fomichev, 1953 drew our attention to the only previously known species of massive colonial rugose corals from Atokan strata of North America that did not bear characteristics of that family. These corals were described by Armstrong (1972) as his new species Lithostrotionella wahooensis and included by him in the Family Lonsdaleiidae Chapman, 1893. Sando (1983, p. 38) briefly commenting on that species, pointed out its morphological similarity to Kleopatrina McCutcheon and Wilson, 1963, and included it in the Family Durhaminidae. However, he considered it homeomorphic rather than related to that Permian genus. Flügel (1974, p. 98) also mentioned 'L.' wahooensis in the context of its relationship or similarity to Minatoa. We have not conducted a detailed restudy of Armstrong's entire collection, since that is beyond the scope of the present paper, but we revised the holotype and one paratype colony 

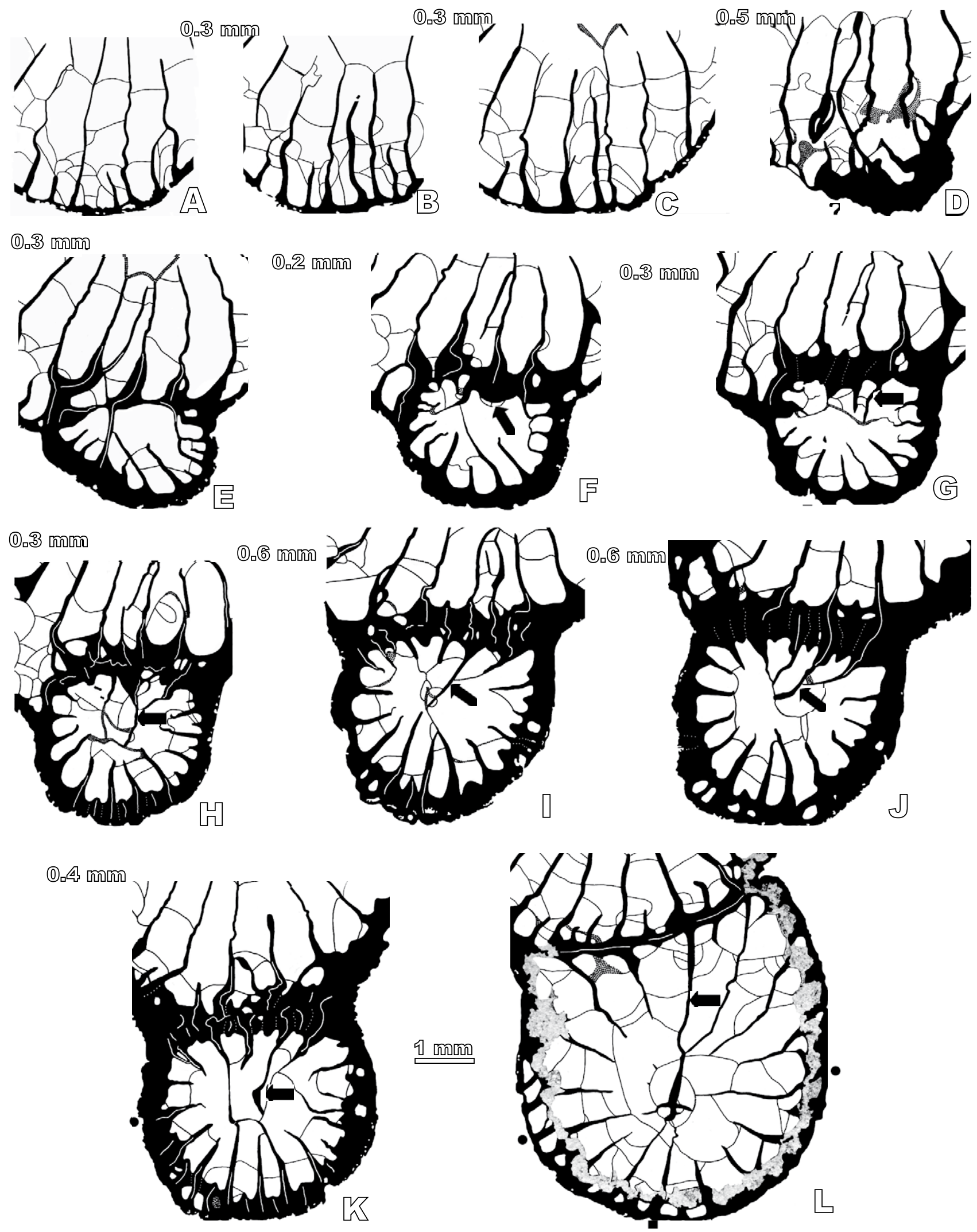

FIGURE 7. Paraheritschioides katvalae sp. nov. Holotype. USNM 545247 = FH-C-F2 \#2. A-K) Blastogeny. Successive growth stages based on serial peels spaced as indicated. L) Young corallite with simple axial structure connected to parent by partition. Distances between particular drawings of growth stages indicated. Scale bar between $\mathrm{K}$ and $\mathrm{L}$ corresponds to all drawings. 
which are compared with a colony collected from the Kuiu Island area. The following was established: i) The generic name Lithostrotionella applied by Armstrong (1972) is inappropriate as this genus possibly is a junior synonym of Petalaxis (see Bamber and Fedorowski, 1998; p. 22). None of the colonies illustrated by Armstrong (1972) and restudied by us exhibits petalaxid features. ii) The morphological differences between individual colonies originally included in Lithostrotionella wahooensis are much greater than acceptable for intraspecific variability. One of those colonies is described below as A. simplex sp. nov., whereas the remaining ones were not revised. The colony illustrated by Armstrong (1972; pl. 6, fig. 4) probably belongs to still another separate new species. iii) The morphological similarity of the colonies from the Kuiu Island area and the Brooks Range allows their placement in the same genus. That in turn augments the similarity of the total fauna from those two regions of Alaska and strengthens our conclusions concerning the paleogeography.

\section{Arctistrotion variabilis sp. nov.}

Figures 8-10

Holotype. USNM 545248, USGS location 27727-PC from Kuiu Island.

Type locality. Southwest shore of islet 0.2 mile northeast of northeast shore of Kuiu Island, lat. 56 $55.74^{\prime} \mathrm{N}, 134^{\circ}$ $12.39^{\prime} \mathrm{W}$.

Type horizon. Crinoidal limestone unit. Bashkirian in age.

Name derivation. Latin variabilis (variable) after variable morphology of axial structure and dissepimentarium between and within corallites.

Material. Holotype specimen listed above. Small, hemispherical colony, originally slightly greater than $6 \mathrm{~cm}$ in diameter with five transverse and four longitudinal thin sections, and seven peels.

Diagnosis. Arctistrotion with maximum n:d value 19:6.0mm;16:5.0mm - 18:5.5mm prevailing; some major septa reach median lamella when axial structure complex or approach axis when median lamella disappears; minor septa restricted to narrow dissepimentarium; tabulae mostly complete.

Description. Corallum massive, cerioid-aphroid (Fig. 8G, I, J). Partitions about $0.4 \mathrm{~mm}$ thick when septothecal, thinner when peripheral margins of major and minor septa lose direct contact (Fig. 9A, C [upper], respectively). Maximum corallite diameter $6 \mathrm{~mm}$. N:d values of mature corallites, 15:5.0mm, 16:5.0mm, 18:5.5mm, and 19:6mm. Major septa long, commonly constitute part of axial structure with thickened inner margins when mature or thin in young corallites (Fig. $8 \mathrm{E}, \mathrm{D}$, respectively), thick at wall tapering innerward (Fig. 8G, I, J). Minor septa very short, wedge-shaped, commonly underdeveloped except within intercorallite walls where they participate in formation of septotheca. Axial structure variable (Fig. 8A, D-F), typically narrow, consists of thickened median lamella commonly confluent with opposing cardinal and counter septa, up to 12 septal lamellae (commonly less) and/or inner margins of major septa, and inner margins of elevated tabulae. Median lamella may be thin and irregular or temporarily disappear (Fig. $8 \mathrm{~F}, \mathrm{~A}$, respectively). In longitudinal section (Fig. $8 \mathrm{H}$ ) continuous axial structure with nearly continuous axial column commonly composed of one row of steeply dipping axial tabellae on each side of median lamella; protrudes high above calice floor (Fig. 8B, C). Three corallites lacking axial structure (Fig. 8G, I, J) in transverse sections suggest intermittent interruption of axial structure. Dissepimentarium composed of one to three ranks of small globose, interseptal dissepiments, dipping at $45^{\circ}$ or slightly more, rarely discontinuous; lonsdaleoid dissepiments may occur near corallite corners. Tabularium normal (Fig. 8B, C, H), composed of complete and incomplete tabulae moderately inclined upward to axial structure, $18-24 / \mathrm{cm}$. Periaxial tabellae elevated, peripheral tabellae almost horizontal.

Early growth stages variable. Typical blastogeny took place in parent's corner; begins with division of one parent's major septum into inner part left within parent's inner dissepimentarium, and peripheral part (Fig. 10A, B white arrow) that constitutes cardinal septum at beginning of offset's formation (Fig. 10C, D, white arrows). Left alar septum (Fig. 10C, white quadrangle), a neoseptum as all other septa in offset inserted during offsetting. Right alar septum (Fig. 10D, right white quadrangle), a neoseptum, very thin and short when inserted. Remaining major septa of cardinal quadrants inserted as typical for the Rugosa (Fig. 10E-G).

Formation of septa offset's in counter quadrants begins with variable modifications of parent corallite septa at parent/offset common zone (Fig. 10C-F). Those modifications end with formation of three thick bodies (Fig. 10F) that either give rise to or form bases for offset's counter septum (middle body) and counter-lateral septa. Inner margin of cardinal septum connected with thin counter septum to form a very thin tabula-like, axial septum. Insertion of septa in counter quadrants rapid, taking place within $0.2 \mathrm{~mm}$ of corallite growth. During that very short distance partition formed from thick bodies mentioned above. Very thin inner margins of some major septa, including cardinal and counter septa, meet at corallite axis to initiate axial structure (Fig. 10G). That very tenuous 

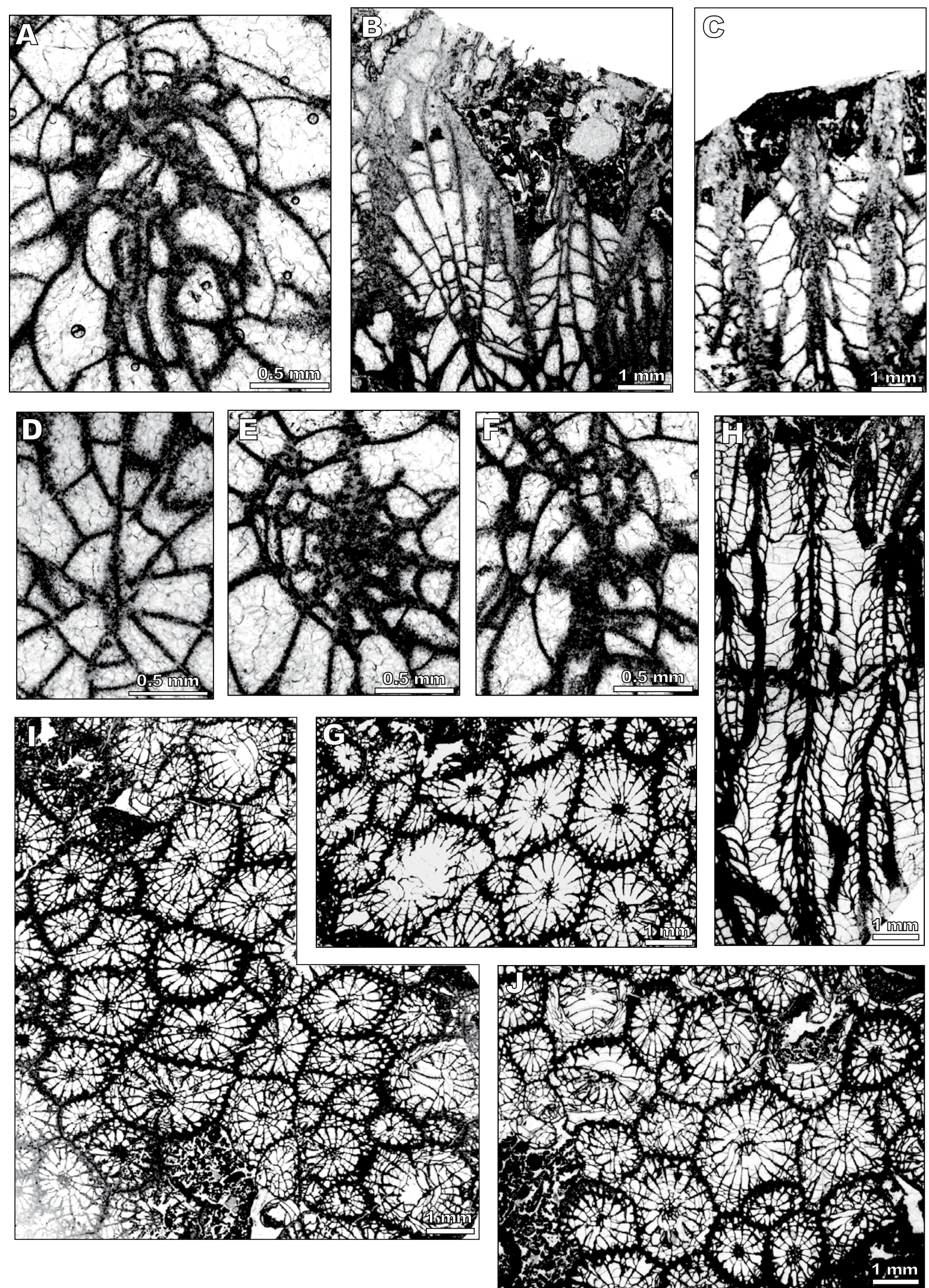

FIGURE 8. Arctistrotion variabilis sp. nov. Holotype. USNM545248 = 27727 PC. A, D-G, I, J) Transverse sections; A, D-F) show variability of axial structures; B , C) oblique sections of calices showing elevated axial structure; G, I, J) transverse thin sections of different parts of colony; H) well oriented longitudinal thin section of mature corallite. Magnification of each figure shown by bar. 

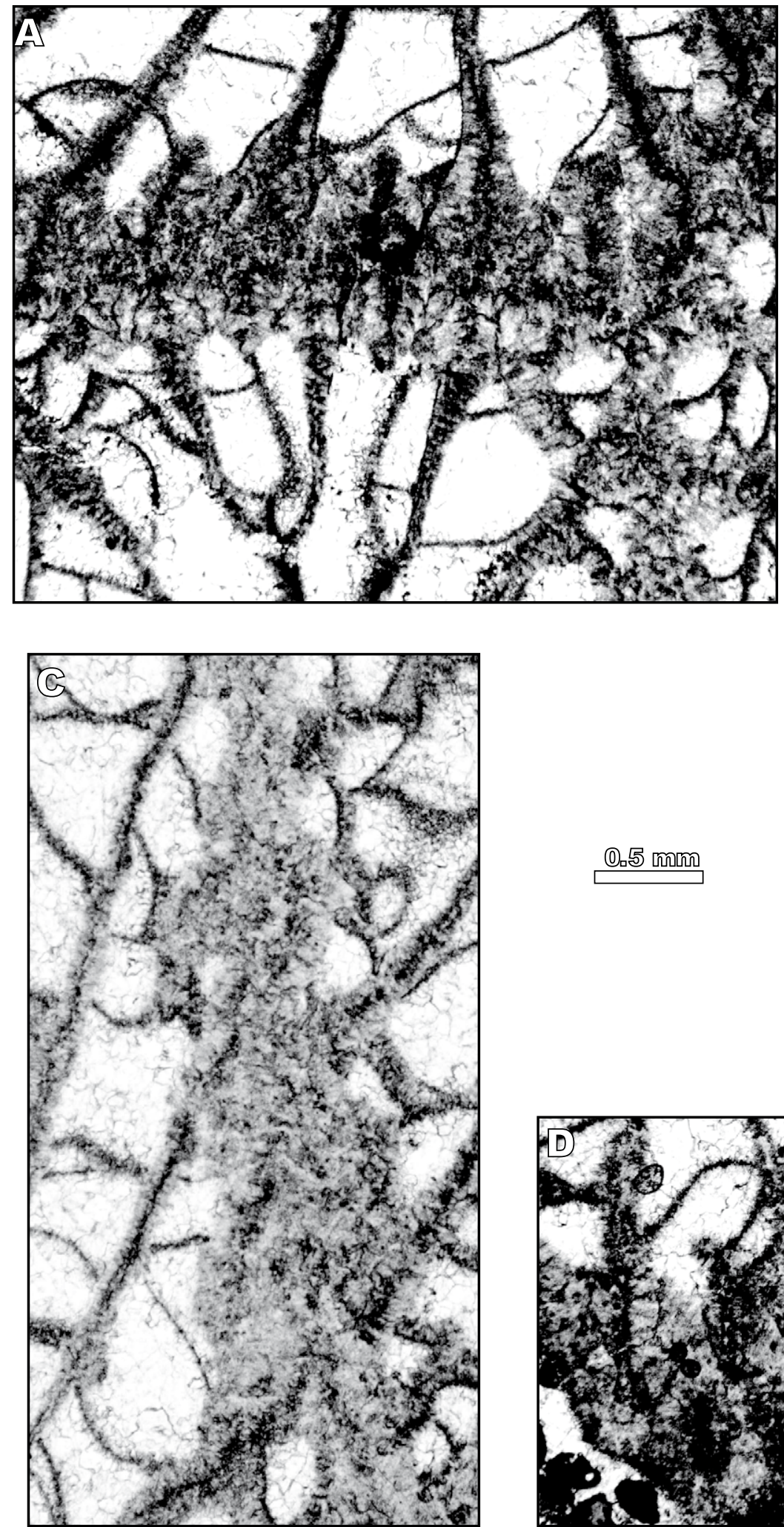
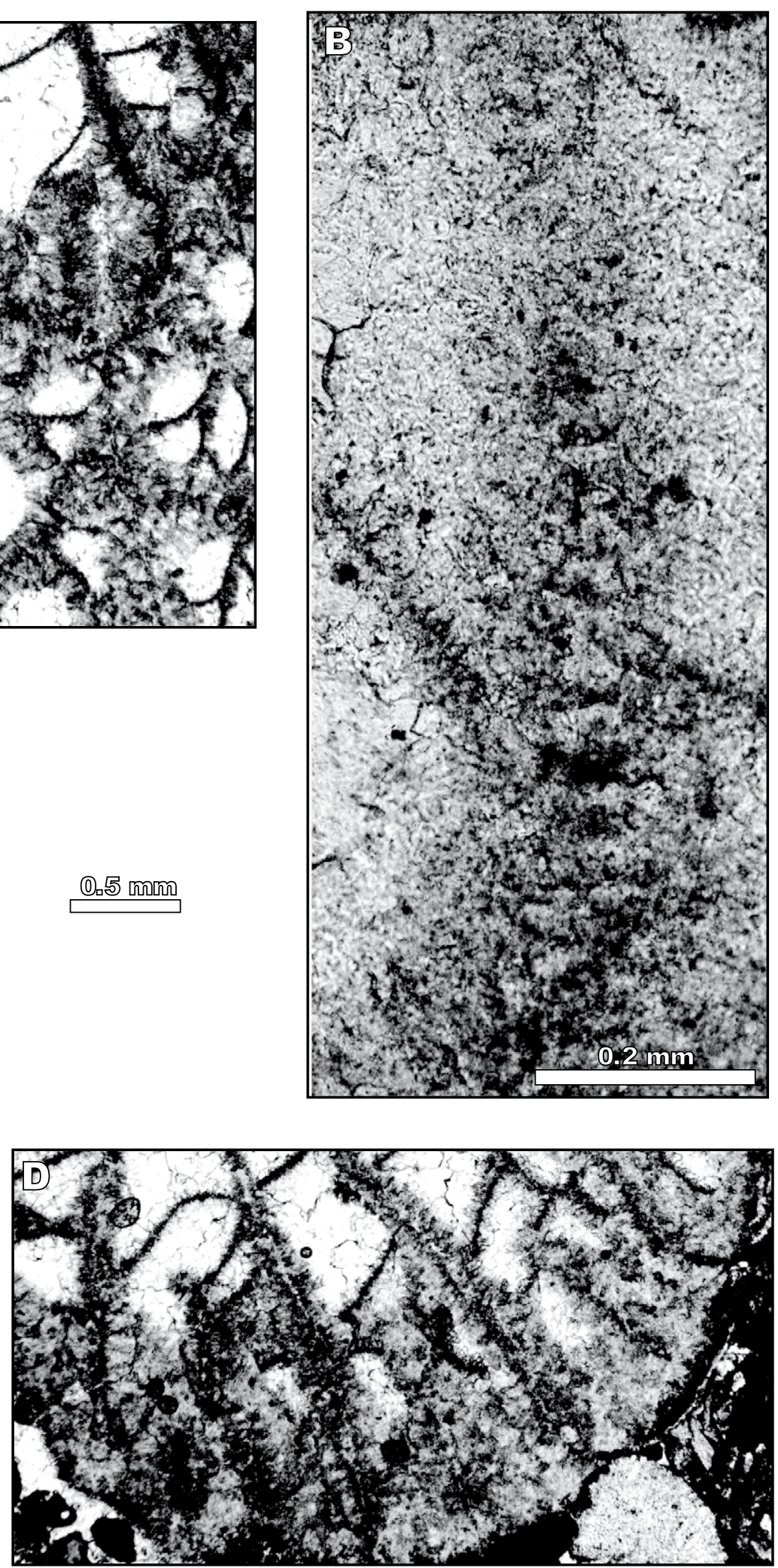

FIGURE 9. Arctistrotion variabilis sp. nov. Holotype. USNM545248 $=27727$ PC. A, B, D) Transverse sections; A) septothecal partition; most septa common for adjacent corallites; B) suspected remnants of trabeculae in diagenetically altered major septum; C) longitudinal section of partition; D) septotheca of corallite partly isolated from colony. Scale bar corresponds to all images except B. 

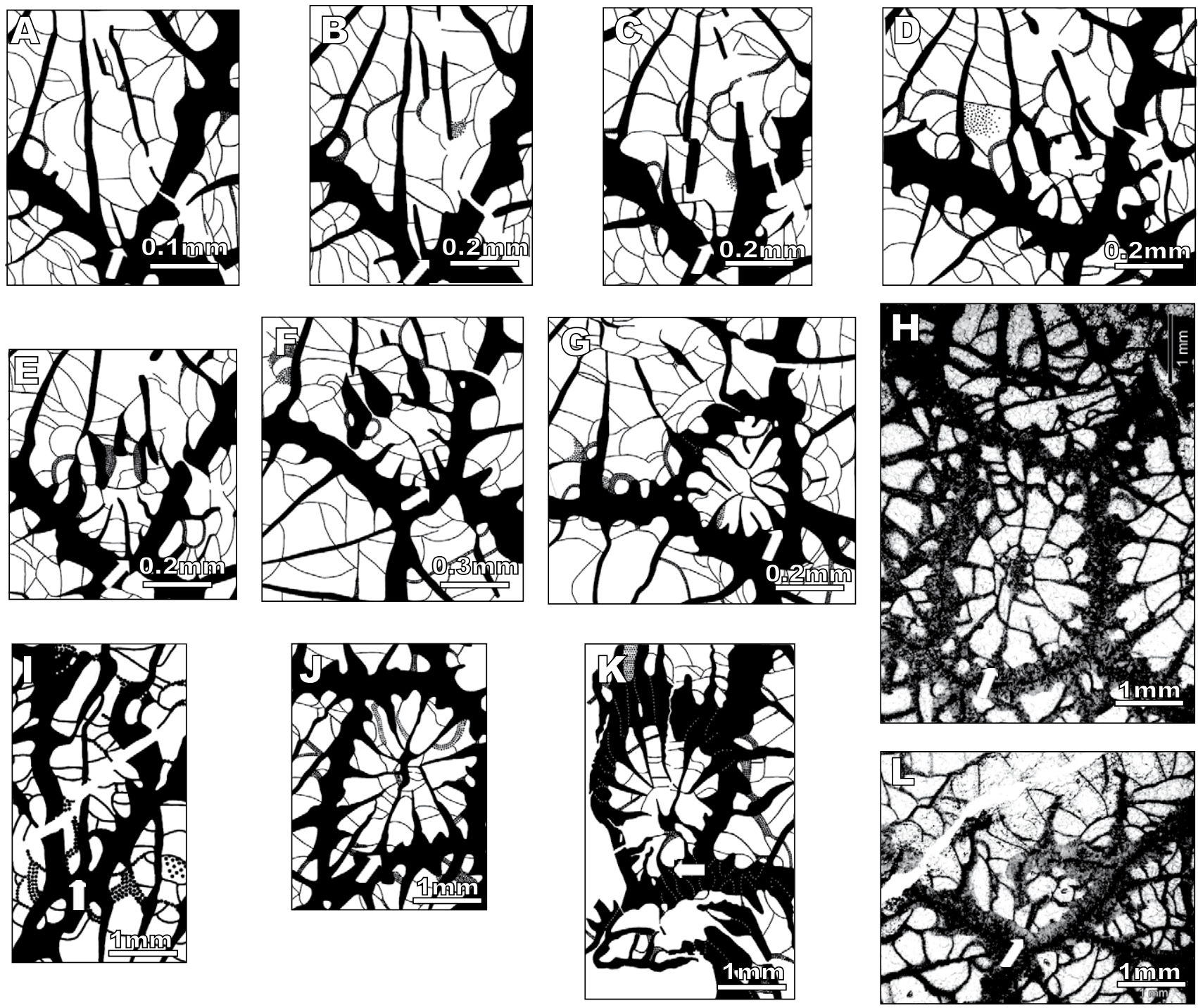

FIGURE 10. Arctistrotion variabilis sp. nov. Holotype. USNM545248 = 27727 PC. Transverse sections; A-G) successiveimages of blastogeny typical for the species and genus based on serial peels spaced as indicated; I, L) offsets illustrating variations in the blastogeny; $\mathrm{H}$, J, K growth stages more advanced than achieved by corallite illustrated in A-G. Scale bar corresponds to all images. Arrows point to cardinal septum, white quadrangles point to alar septa.

connection strengthens in further growth to form more or less thickened median lamella (Fig. 10H, J, K). Strong, continuous axial septum may be developed by some offsets in early growth stages (Fig. 10I, white arrow). Also, strong cardinal septum may be only recognizable septum in cardinal quadrants, whereas three septa occur at same time in counter quadrants (Fig. 10L). Solid partition surrounds almost $2 / 3$ of offset, leaving only narrow duct near parent's external wall, apparently closed by section of a tabula. This morphology strangest among all offsets observed.

Regardless of variability in offsetting, main characters in common are: i) Inheritance of only cardinal septum by offset from parent; ii) Appearance of axial septum after several major septa already present in offset; iii) Formation of axial structure from axial septum which establishes bilateral symmetry in arrangement of septa.

Microstructure of septa (Fig. 9B), intercorallite wall (Fig. 9A, C), and external wall of partly isolated corallite (Fig. 9D) diagenetically altered and difficult or impossible to reconstruct. Finely trabecular microstructure of septa demonstrated by irregular fans of fibrils isolated from one another (Fig. 9B, middle row). Partition septothecal in character adequately demonstrated by several intercorallite walls seen in transverse sections and in longitudinal section composed of peripheral oblique margins of septa (Fig. 9A, $\mathrm{C}$, respectively). 
Discussion. This species is the type species for the genus. For remarks at the species level see discussion on A. wahooense (Armstrong, 1972) and A. simplex sp. nov. below.

Occurrence and Age. See holotype.

\section{Arctistrotion wahooense (ARMSTRONG, 1972)}

\section{Figure 11}

e.p. 1972. Lithostrotionella wahooensis ARMSTRONG, p. 14 , pl. 5, fig. 1, pl. 6, figs. 1-3, pl. 7, figs. 1, 2 only.

Material. Armstrong's (1972) specimens and thin sections included by him in "Lithostrotionella" wahooensis comprise colonies with morphological differences unacceptable for intraspecific variability. Therefore, only colony USNM 160527 (Armstrong, 1972; pl. 5, fig. 1) in addition to holotype is left here in that species. Significant diagenetic alterations preclude microstructural and blastogenetic studies. The largest and smallest diameters are measured and pointed out in $\mathrm{n}$ :d values because neither of them alone is appropriate for corallites very irregular in shape.

Diagnosis. Arctistrotion with n:d values 19:5.0x7.2mm to $22: 7.0 \times 8.0 \mathrm{~mm}$; major septa commonly approaching continuous axial structure with discontinuous axial column, some incorporated into it; cardinal septum slightly shortened in some; counter septum commonly meets median lamella; minor septa variable in length, most restricted to peripheral dissepimentarium that reaches up to $1 / 3$ corallite radius; incipient pseudonaotic structures in some corallites; lonsdaleoid dissepiments distributed irregularly.

Description. Corallites vary considerably in shape. Most elongated, few regularly hexagonal. $\mathrm{N}: \mathrm{d}$ values samples: 20:5.8x9.5mm, 20:6.0x11.0mm, 21:6.5x9.5mm, $22: 6.5 \times 7.0 \mathrm{~mm}, 22: 5.2 \times 9.0 \mathrm{~mm}$. External wall commonly diagenetically altered precluding recognition of its character (Fig. $11 \mathrm{C}$ ). Some oblique sections with thick peripheral sectors of septa, common for adjacent corallites (Fig. 11D, dark bodies), document partition type of intercorallite walls, i.e. cerioid-aphroid growth form of colonies studied. In transverse sections (Fig. 11A) major septa thin, slightly wavy, especially in dissepimentarium, rarely terminated far from axial structure, more commonly approach that structure with some incorporated. Their amplexoid character documented by short segments attached to sections of tabulae in some corallites. Cardinal septum equal to adjacent major septa in most, slightly shortened in some corallites. Cardinal fossula absent. Counter septum commonly elongated and attached to slightly thickened median lamella which constitutes symmetry axis in most corallites. Most minor septa restricted to outer part of dissepimentarium, some reach its inner margin, several interrupted by small lonsdaleoid dissepiments. Axial structure variable, but median lamella permanently present although wavy, thin, and hardly recognizable in some corallites. Septal lamellae and/or inner margins of major septa vary in number from one to five on each side of median lamella, maximum number rare and only at one side of axial structure. Tabularium mostly normal, but some fragments (Fig. 11B, arrow) with long concave, complete tabulae and convex or horizontal tabellae attached to them at periphery suggest biformity. Axial tabellae or inner margins of tabulae irregular in shape, arrangement and number. Axial structure seen in longitudinal sections variable (Armstrong, 1972; pl. 6, figs. 2, 3; Fig. 11B). Only median lamella permanent, sometimes accompanied by inner margins of steeply elevated complete tabulae, tabellae, or incomplete tabulae when axial column absent; very steeply arranged axial tabellae, including rare peripheral tabellae when axial column present. Dissepimentarium approximately $1 / 3$ or slightly less corallite radius in width, in some corallites composed mostly of irregular interseptal dissepiments, in others some small lonsdaleoid, pseudonaotic (Fig. 11C), lateral and pseudoherringbone dissepiments present (Fig. 11A, left and right sides of colony, respectively). Lonsdaleoid dissepiments rare, differentiated in size and position within dissepimentaria, interrupting either both major and minor septa or only the latter.

Discussion. A small $(5.5 \times 4.0 \times 2.0 \mathrm{~cm})$, poorly preserved fragment of the holotype of $A$. wahooense available for the study differs from $A$. variablis in its simpler axial structure with axial column rarely present, shorter major septa, much wider and more complex dissepimentarium and thinner partitions with probable incomplete septotheca. A. kabyaiensis (Kawamura and Stevens, 2012) is generally very similar to $A$. wahooensis in its simplicity. It differs in having fewer major septa and slightly smaller corallite diameters.

Occurrence and Age. Wahoo Limestone, 48 feet below the top of the top of the Saddlerochit Mountains section 69A-1. (After Armstrong, 1972; captions to pl. 6, figs 1-3). Atokan (Bashkirian) in age.

\section{Arctistrotion simplex sp. nov.}

Figure 12

e.p. 1972. Lithostrotionella wahooensis ARMSTRONG, p. 14 , pl. 6 , fig. 5 only.

\section{Holotype. USNM 160529.}

Type locality. "Upper 75 feet of the Wahoo Limestone, Sadlerochit Mountain section 68A-3" (After Armstrong, 1972; caption to pl. 6, fig. 5). Age Atokan (Bashkirian). 

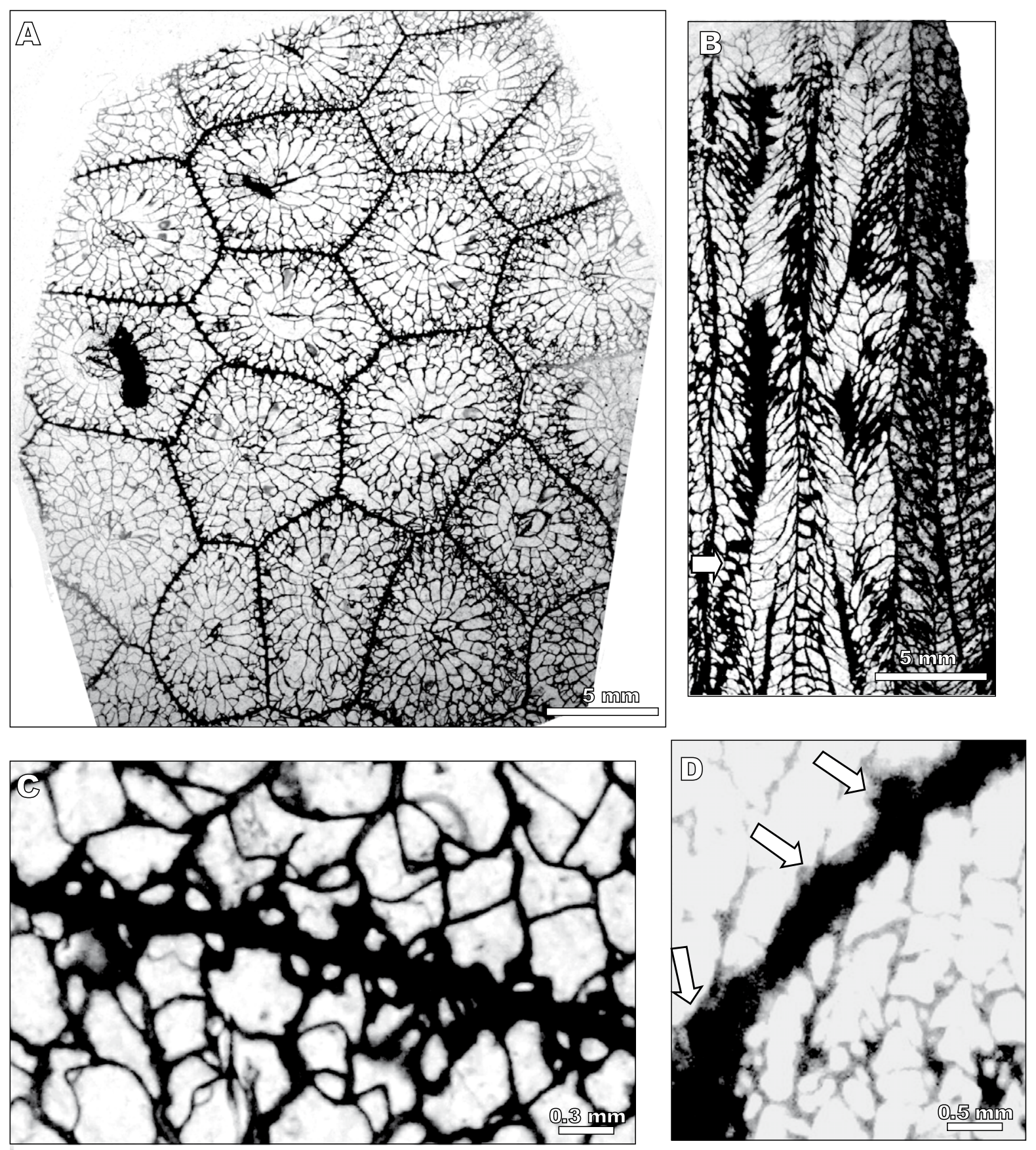

FIGURE 11. Arctistrotion wahooense (Armstrong, 1972). A) Transverse section (= Armstrong, 1972; pl. 6, fig. 1); B) longitudinal section (= Armstrong, 1972; pl. 6, fig. 2), complete tabulae, possibly biform, pointed to by arrow; C) transverse section of pseudonaotic septa near partition; D) oblique section of partition with peripheral parts of septa common for adjacent corallites (darkest lenticular bodies; some pointed to by arrows). Magnification of each figure shown by bar.

Name derivation: Latin simplex (simple) after its more simple morphology as compared to both the type species and $A$. wahooense.

Material. Only the holotype, considered by Armstrong (1972) a paratype of 'L.' wahooensis, is included in this species. Specimen significantly silicified, precluding blastogenetic and microstructural studies. Almost completely preserved calice ridges of some corallites (Fig. $12 \mathrm{E}$ ) and remnants of peripheral segments of septa allow documentation of partition (Fig. 12C). One transverse and one longitudinal thin section was made in addition to Armstrong's (1972; pl. 6, fig. 5) thin section re-illustrated here. 
Diagnosis. Arctistrotion with n:d mean values 2325:7.8-9.0mm; 25:8.5-9.0mm prevailing; major septa isolated from median lamella; cardinal septum commonly free, equivalent to other major septa in length; axial structure rarely discontinuous, restricted to thin median lamella with 1-2 short septal lamellae on each side; minor septa variable in length, some intersect dissepimentarium that reaches up to $1 / 3$ corallite radius.

Description. Presence of partition rather than dividing wall suggested by three facts: i) Position of septa in adjacent corallites mostly opposite one another (Fig. 12A). Such arrangement typical for fully integrated colonies. ii) Remnants of peripheral margins of major and minor septa extend towards two adjacent corallites (Fig. 12C). iii) Septa of adjacent corallites meet at intercalicular ridges (Fig. 12E).

Most corallites elongated with n:d ratios $23: 5.1 \times 10.5 \mathrm{~mm}, \quad 24: 7.1 \times 10.5 \mathrm{~mm}, \quad 25: 6.6 \times 9.6 \mathrm{~mm}$, 25:6.8x11.0mm, 25:9.0x9.0mm. Most major septa complete, equal in length, radially arranged, straight in tabularium, slightly wavy in dissepimentarium, not approaching axial structure. Cardinal septum equal to other major septa in length. Cardinal fossula absent. Counter septum rarely extends to thin, irregular median lamella free from septa in most corallites. Connection of both protosepta to median lamella very rare (Fig. 12B). Minor septa vary in length from short segments attached to external wall (Fig. 12B) to long ones crossing entire width of dissepimentarium without penetrating tabularium (Fig. 12A, several corallites). Axial structure restricted to median lamella with 1-2 very short septal lamellae in some, rarely interrupted. Axial column lacking. Tabulae incomplete, at periphery nearly horizontal, elevated towards median lamella at $45^{\circ}-55^{\circ}$ (Fig. 12D). Dissepimentarium 1/4-1/3 corallite radius. Dissepiments mostly irregular, interseptal. Lonsdaleoid dissepiments rare, interrupt either minor septa only or both cycles in some corallites.

Discussion. This species differs from the type species in the larger number of septa, greater corallite diameters, major septa not approaching a mostly thin, wavy median lamella, a simple axial structure, and a much wider dissepimentarium. It is morphologically closer to A. wahooense, but differs from that species in its larger number of septa at similar or slightly larger mean diameters, in an almost radial arrangement of free ended major septa, in lacking an axial column, in having minor septa of very variable length with several intersecting the dissepimentarium, and with pseudonaotic structures absent or underdeveloped.

Occurrence and Age. See holotype.

\section{CONSIDERATIONS}

\section{Relationships vs morphological similarity}

Fasciculate colonies are common among the Pennsylvanian Rugosa. Some true genera, such as Copia Vassilyuk and Kozyreva, 1974, were either short-lived or rare and have not been recorded after their first recognition. Some others, such as Heintzella Fedorowski, 1967, extending from late Serpukhovian to early Sakmarian (Tastubian), may comprise both related species and unrelated, but closely comparable morphotypes. Also, there are other taxa, such as Heritschioides Yabe, 1950, for which true relationships and stratigraphic positions were previously incorrectly interpreted (see Fedorowski et al. 2014a). The most commonly described taxa and/or generic names of taxa, important for phylogenetic, palaeogeographic or stratigraphic syntheses are briefly listed and discussed below. The phrase "generic names of taxa" means that we are in fact dealing with morphotypes rather than true genera. Not all records, but only examples cited below, not including Permian records include: Corwenia.

Corwenia (e.g. Smith and Ryder, 1926; Gorsky, 1951; de Groot, 1963; Fedorowski and Goryanov, 1973; Rodríguez, 1984; Wu and Zhao, 1989). Paraheritschioides (e.g. Sando, 1985; Flügel, 1994; Lin et al., 1995; Fan et al., 2003; Fedorowski et al., 2007). Fischerina = Heintzella (e.g. Stuckenberg, 1904; Fedorowski, 1965; Ivanovsky, 1976; Degtjarev, 1979); Heintzella (e.g. Fedorowski, 1967; Fedorowski et al., 2007 (see pp. 88, 89 for synonymy); Ivanovsky, 1976, 1987; Hill, 1981; Lin et al., 1995; Chwieduk, 2013); Profischerina (Cotton, 1973; Somerville, 1997; Kossovaya, 1997); Opiphyllum (e.g. Kozyreva, 1973; Wu and Zhao, 1989); Fomichevella (Fedorowski, 1975; Fedorowski et al., 2007 (see pp.80, 81 for synonymy and complete list of authors)); Lophophyllum (Koninckophylloides subgen. nov.) (Gorsky, 1978); Koninckophylloides (Degtjarev, 1979; Kossovaya, 1997); Protodurhamina (Kozyreva, 1978); "Koninckophyllum" (Degtjarev, 1979); and Sestrophyllum (Wu and Zhao, 1989). The large number of generic names listed above reflects both actual different combinations of morphological features and the instability of several of those characters within the same colony. An incomplete investigation of many previously described specimens, the lack of blastogenetic and microstructural data in particular, prevents close comparison of colonies bearing names listed above and probably has resulted in numerous synonymies. Although the unnecessary multiplication of names is suspected, it cannot be proven. Also, the list of names and papers dealing with Pennsylvanian fasciculate colonial Rugosa cited here is incomplete. The papers mentioned above, however, exemplify the morphological variability of such colonies used for the recognition of various hypothetical lineages. 

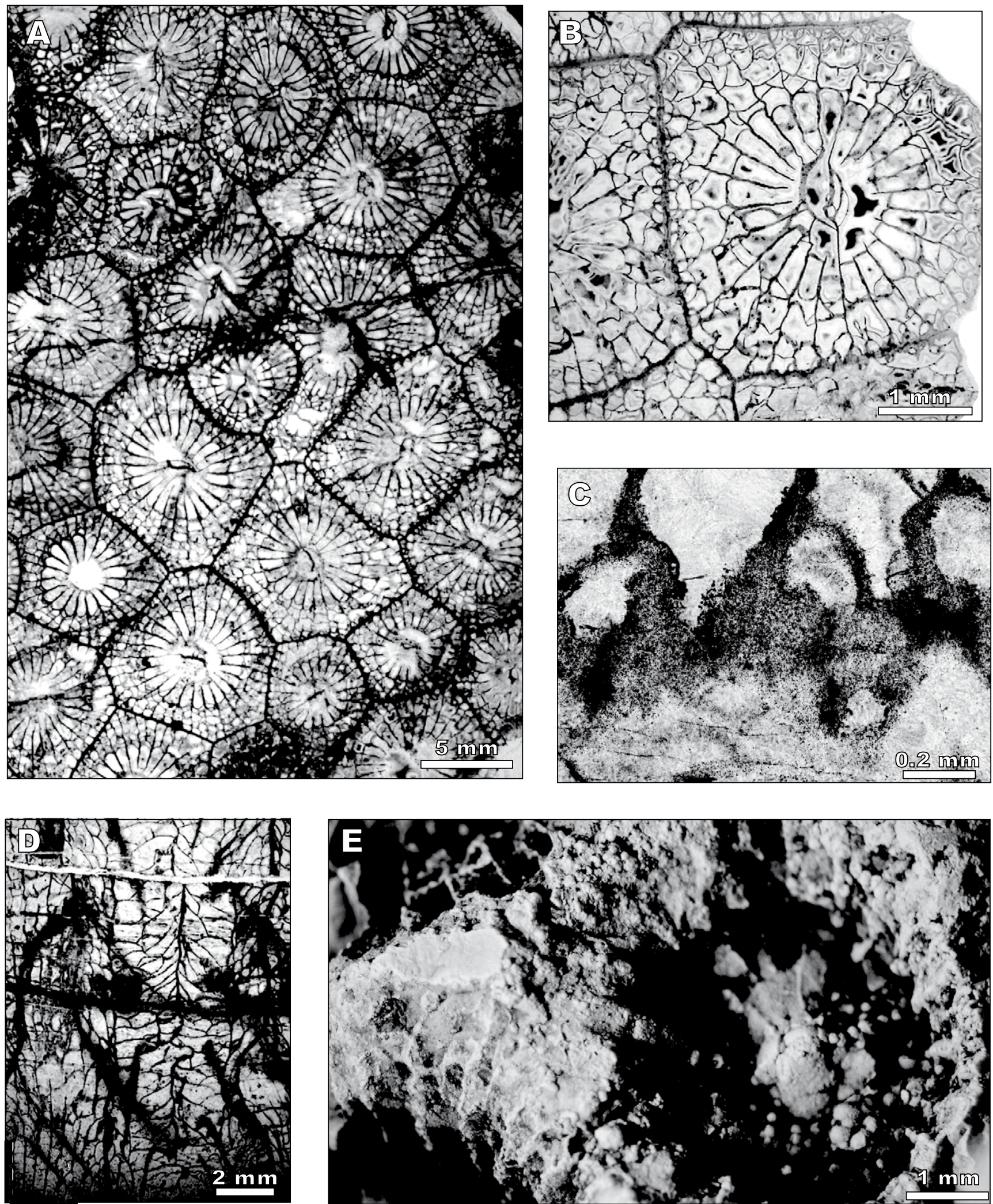

FIGURE 12. Arctistrotion simplex sp. nov. Holotype. USNM 160529. A-C) Transverse thin sections; A) general view (= Armstrong, 1972; pl. 6, fig. 5); B) photo showing thin median lamella connected to both protosepta; C) remnants of major and minor septa common for adjacent corallites in partition replaced by silica; D) slightly oblique longitudinal section; E) slightly incomplete uppermost ridges of calices with uppermost margins of septa common for adjacent corallites. Magnification of each image indicated by bars. 
The genera treated in this paper contain colonies, the mature morphology of which allows various approaches to their taxonomic position. Here we explain our reasons for such an approach to those taxa, especially Corwenia, and to the taxonomy in general.

The holotype must by definition possess characteristics to which all other specimens of similar morphology are compared in order to establish their true relationships. This simple rule is not always followed. Some authors use broad diagnoses of species and genera in order to include their specimens in certain taxa, commonly ignoring such characters as the microstructure of septa, the hystero-ontogeny, difference in stratigraphic position and their palaeogeography. The latter two factors and the fact that somatic changes follow the genetic ones with a considerable delay may result in placing unrelated taxa together. At the other extreme there is splitting unsupported by qualitative differences. Unfortunately, both have been applied to Pennsylvanian and Permian fasciculate colonies of the Rugosa. Many poorly supported or non-supported generic names were applied to such colonies (see above). Several of them superficially resemble Corwenia. Thus, the remarks that follow begin with that genus.

Two main facts allow different approaches to Corwenia: i) The inclusion by Smith and Ryder (1926) in their new genus Corwenia of two morphologically distant species: Lonsdaleia rugosa McCoy, 1849, and their new species Corwenia vaga. They did so in spite of the differences between those two species recognized by them (see below). ii) Inconsistent and weakly expressed characters appear in various combinations within certain fasciculate colonies. Repetitions of morphological similarities also are numerous in Pennsylvanian and Permian colonies. Thus, recognition of the true diagnostic characters for a given taxon is possible only when various other features are considered, including the hystero-ontogeny, microstructure of septa and the palaeogeography of the taxa.

The corweniid characters of the overwhelming number of the Pennsylvanian and Permian fasciculate colonies of the Rugosa are seldom comparable to Corwenia rugosa, the type species for the genus, but they do rather closely resemble C. vaga. Thus, the main criterion for comparison is based on the latter species rather than on the type species. The axial structure of $C$. vaga ranges from a median lamella in an axial column, clearly isolated from a tabularium by lateral tabellae at one extreme, to a simple interrupted median lamella, not accompanied by septal lamellae at the opposite extreme (Smith and Ryder, 1926, pl. 5, fig. 7 and 6 , respectively). Since these features occur in that species but not in the type for the genus, such morphology cannot be considered typical of that genus. Smith and Ryder (1926, p. 153) characterized the intracolonial variability of $C$. vaga as follows: “... the same degree of difference observed between specimens of simple corals, the extreme would, in the absence of intermediate forms, be interpreted as different species, if not different genera".

C. vaga bears some characters closely comparable to Paraheritschioides, but we do not consider it an ancestor for that genus, because Smith and Ryder (1926, p. 156) characterized its early hystero-ontogeny as follows: "The corallites develop along precisely the same lines as the genotype, but the hystero-brephic stage is more prolonged and its subsequent development is less regular." That means derivation of the pseudocolumella is from the axial septum and connection to the cardinal septum occurs in later corallite growth stages, thus opposite to that in Paraheritschioides. However, some Late Carboniferous colonies (e.g. specimens described by Gorsky (1951) and Fedorowski and Gorianov, 1973) that developed axial structures connected to the cardinal septum and have that structure completely or in part isolated from most major septa, may belong to the lineage either starting from or including $C$. vaga. In addition to that possible progressive lineage that may have given rise to some late Carboniferous genera, the conservative lineage derived from and including Corwenia rugosa continued at least up to the Westphalian (de Groot, 1963; Fedorowski, 2004) without developing obviously different morphological and hystero-ontogenetic features. Thus, two lineages characterized by median lamellae and axial structures derived from and based on the cardinal septum occurred during Bashkirian and Moscovian times. The conservative lineage connected to $C$. rugosa terminated at that time, whereas the progressive lineage connected to $C$. vaga continued, perhaps up to early Cisuralian time.

The taxa possessing axial structures connected to the counter septa form a lineage parallel to the former two. These taxa may have been derived from early representatives of Heintzella. Having different Early Carboniferous roots, the lineage originating perhaps with $C$. vaga, described above as progressive, and the lineage originating perhaps from Heintzella developed similar general morphologies during Late Carboniferous time. However, taxa included in these two lines remain recognizable because of the derivation of their median lamellae and connection of their axial structures to the cardinal septum (in the first lineage) and the counter septum (in the second lineage). Several species of Paraheritschioides in the second lineage extend into the Cisuralian (Lower Permian) of the Cordilleran-ArcticUralian Realm (see Fedorowski et al., 2007 for details).

Either the lineage of $C$. rugosa, described above as conservative, or an unknown species belonging to the Aulophyllum lineage gave rise to the Serpukhovian to Moscovian North American offspring Heritschioides. 
Revision of that genus by Fedorowski et al. (2014a) documents an occurrence of extra septal lamellae in the axial structure of Heritschioides, a character typical for Aulophyllum and some other genera of the Subfamily Aulophyllinae, but absent from the Subfamily Dibunophyllinae that includes Corwenia. Thus, inclusion of Heritschioides within the Family Aulophyllidae seems logical and well supported, as is its separate status as the Subfamily Heritschioidinae (see Fedorowski et al., 2014a for comprehensive discussion). That subfamily is unknown so far from other continents, but occurs in the Bashkirian and Moscovian strata of both the northern part of Alaska and some accreted terranes along the western margin of North America.

Thus, at least four different lineages are recognizable within the fasciculate colonies from Late Carboniferous strata. Three of them, i.e. the conservative Corwenia rugosa lineage, the progressive $C$. vaga lineage, and the Heritschioides columbicum lineage developed within the Family Aulophyllidae, whereas the fourth one, including Paraheritschioides, developed within the Family Kleopatrinidae. The content of those lineages is not proposed here because many Late Carboniferous and Cisuralian colonial, fasciculate genera named so far are superficially described and their blastogeny and the microstructure of septa remain unknown.

Rodríguez and Somerville (2010) have already drawn attention to the possible polyphyletic status of Corwenia and cited several examples. They postulated derivation of Corwenia s.s. from Dibunophyllum, but did not distinguish between the two species originally included by Smith and Ryder (1926) in that genus. Also, they did not draw attention to remarks by those authors concerning Smith and Ryder's new species $C$. vaga. The paper by Rodríguez and Somerville (2010) was devoted mainly to the influence of the environment on the development of a colonial fasciculate growth form from a solitary growth form. Although the environment probably plays a selective role in that development, it cannot be the underlying cause; there must be a genetic basis for the appearance of either protocolonies or fully developed colonies. Fedorowski (1978) considered this problem and introduced the term lost structures, i.e. offsets not able to maturate as an intermediate step. This idea was repeated by Fedorowski and Ogar (2013), who formalized the term 'protocolony'.

Examples illustrated by Rodríguez and Somerville (2010) represent local and possibly short-lasting offsprings of Corwenia-like taxa rather than major taxonomic lines. Nevertheless, those examples illustrate the necessity of making a distinction between monophyletic lineages and taxa appearing as incidental offspring of colonies with similar morphotypes.
Only the Family Petalaxidae Fomichev, 1953, which includes massive rugose coral colonies, is nearly cosmopolitan during Late Carboniferous time. Cerioid, cerioid-aphroid and aphroid colonies belonging to other families are common only in the Paleotethys area, particularly in Southern China. The Family Kepingophyllidae Wu and Zhou, 1982, restricted to that far eastern area, is most characteristic, but representatives of some other families co-occur with that family. In contrast, cerioid and cerioid-aphroid colonies, except for the Family Petalaxidae, are very rare in the Late Carboniferous deposits outside of that far eastern area. In addition to the sites and taxa mentioned in remarks to the Subfamily Arctistrotioninae and that subfamily itself, one cerioidaphroid new genus of the Subfamily Heritschioidinae from Kuiu Island (Alaska) is known for us so far (Fedorowski et al., 2014b). Bashkirian fasciculate species of Heritschioides are most likely a distant ancestor for that cerioid-aphroid genus of the Heritschioidinae mentioned above. A cerioid intermediate genus between those two can be predicted if the evolutionary transmission from dendroid through cerioid to cerioid-aphroid colonies, commonly observed within the Rugosa, took place in this particular case.

\section{Palaeogeography}

The Alexander terrane, of which Kuiu Island is a part, and many other allochthonous terranes accreted to the northern and western margins of Pangaea in the Mesozoic have been interpreted by Colpron and Nelson (2011) to have been derived from a region between Baltica, Laurentia, and Siberia, in proximity to the northern Caledonides in early Paleozoic time. Blodgett et al. (2010), on the other hand, have recently suggested that the Alexander terrane originated in eastern Siberia based on Silurian-Middle Devonian megafossils and stratigraphy. Then later in Late Devonian-Early Carboniferous time that terrane rifted away from the Siberian palaeocontinent. In any event, the position of the Alexander terrane in the Late Carboniferous can be inferred from regional distribution of colonial corals of which the present study is a part.

Comparisons of the colonial rugose corals discussed here with previously studied faunas (Armstrong, 1972; Kawamura and Stevens, 2012; Fedorowski et al., 2014b) indicate a substantial similarity between the faunas of Kuiu Island and the Brooks Range in Alaska, and the Eastern Klamath terrane in northern California.

The subfamilies Heritschioidinae and Arctistrotioninae are represented by species unknown elsewhere except for one species of the Heritschioidinae in the Quesnel terrane in southern British Columbia and two possible species of the Arctistrontioninae in Novaya Zemlja and possibly Iran. Thus, although there is little similarity between these coral 
faunas and others elsewhere, there are similarities at the generic and specific levels, as well as at the subfamily level, within the localities mentioned above (see Table 1). For instance, Paraheritschioides jagoensis from the Brooks Range may also be present in the Eastern Klamath terrane, and P. compositus from the Brooks Range is comparable to $P$. katvalae from Kuiu Island. There are also similarities between several species of Arctistrotion. A. variabilis from Kuiu Island, A. wahooense from the Brooks Range, and A. kabyaiensis from the Eastern Klamath terrane all have somewhat similar characteristics. Thus, these faunas suggest that communication and some degree of proximity of these three localities existed in the Late Carboniferous. Communication with Novaya Zemlja and East Iran is more difficult to accept, but this question cannot be answered without a detailed study of Gorsky's specimens from the former region and 'Kleopatrina (Porfirievella)' bashkirica Flügel, 1994 and similar colonies from the latter area.

The following factors should be kept in mind when considering similarities at the generic level and differences at the specific level: i) The possibility of dispersion. This depends on the length of the larval phase, the direction of currents, the appropriate environment for larvae to metamorphose, and the distance between areas colonized by corals. Little or nothing is known about those preconditions. ii) Time of occurrence of the genera at different sites. Dating is imprecise for accurate comparisons. Apparently the Iranian fauna is stratigraphically oldest (Declinognathodus lateralis and Millerella Zone), and the Kuiu Island fauna is youngest (Bashkirian and Moscovian). Some species from the Novaya Zemlja may be Serpukhovian. However both their locality and age are approximate, so they should be recollected and restudied prior to being taken into consideration. iii) Distances between particular sites and their precise positions at a given time can be calculated as only very approximate. These sites may have been hundreds or thousands of miles apart and hundreds of thousands years apart in time. iv) Bias in collecting. Specimens derived from both Alaskan sites, Novaya Zemlja and Iran were collected by stratigraphers as examples of the faunas present, but not by paleontologists for comprehensive paleontological studies. Taking all those factors in mind, the differences at the specific level between the faunas discussed here is not surprising. Thus, speciation may have occurred during the possible hundreds of thousands of years the various faunas may have been isolated. Also, we are dealing with small remnants of former oceanic platforms, and intermediate sites between areas represented by the known faunas may have existed in which speciation took place.

In contrast to species, the similarity in content of faunas at the generic and subfamily level suggests an absence of barriers between individual sites that would had precluded an exchange of rugose coral faunas. We consider such a communication was most likely, although we cannot point to a precise direction or directions of dispersal and the timing of the exchanges. This will be possible when the ages are more precisely established.

The Alaska Range has been considered to have been essentially in place in northern Alaska by Pennsylvanian to Permian time (Colpron and Nelson, 2011) at about $40^{\circ} \mathrm{N}$. Pennsylvanian paleolatitudes for the Kuiu Island and the Eastern Klamath terranes are unavailable. However, the paleolatitude of the Permian Halleck Volcanics on Kuiu Island was determined to be somewhat farther south from the Brooks Range at $\sim 25^{\circ} \mathrm{N}$ (Butler et al., 1997). The greater complexity of some of the corals in the Kuiu terrane e.g. a new cerioid genus (Fedorowski et al., 2014b), also tends to suggest warmer water conditions at a lower latitude than the Brooks Range. Permian rocks of the Eastern Klamath terrane have a paleolatitude of about $18^{\circ} \mathrm{N}$ (Mankinen et al., 1989). However, positions of these two terranes in the Upper Carboniferous may have been farther north. Nevertheless, we suggest that the northern part of North America (northern Alaska) and the Alexander and Eastern Klamath terranes, which probably lay somewhat farther south out in the Panthalassa Ocean, were close enough together during the Late Carboniferous that exchange of taxa was possible.

\section{SUMMARY}

This study involves description and discussion of Upper Carboniferous colonial rugose corals from two areas in Alaska: the Kuiu Island area, and the Brooks Range. The fauna from the Brooks Range, originally described by Armstrong (1972), is revised and several new species are erected. In addition, two new species from the Kuiu Island area are described for the first time. Besides new species, one new genus and one new subfamily are recognized.

A study of the blastogeny conducted here along with previous works (papers cited in the Relationships vs morphological similarity subchapter above and Fedorowski et al., 2014a, b) shows that at least four parallel evolutionary lines of fasciculate corals developed in the Late Carboniferous. These lineages may be traced back to Corwenia rugosa, C. vaga, an unknown ancestor of Heritschioides columbicum and Heintzella.

The faunas described here bear considerable resemblance to one another and to an Upper Carboniferous fauna in the Eastern Klamath terrane in northern California and, perhaps to Northern Iran and Novaya Zemlja. This similarity suggests that there was open communication between these areas in the Late Carboniferous. 


\section{ACKNOWLEDGMENTS}

We are grateful to Charles Henderson for his work on conodont faunas which forms the basis for age determinations of corals from the Kuiu Island area. We also thank E. Katvala who collected some of the specimens utilized in this study, and we want to express our appreciation to the critical readers, Olga Kossovaya , VSEGEI, St. Petersburg, Russia, and Marcus Aretz, Université Paul Sabatier Toulouse, France, for their helpful remarks on the manuscript. We also thank Marta Bartkowiak, MSc. from the Institute of Geology, A. Mickiewicz University for her technical assistance. All facilities and the financial support for Fedorowski were supplied by Adam Mickiewicz University, Poznań, Poland. Facilities were provided for Stevens by the Department of Geology at San Jose State University. Finally we are grateful to the Smithsonian Institution, National Museum of Natural History for the loan of specimens from the Brooks Range, Alaska.

\section{REFERENCES}

Armstrong, A.K., 1972. Pennsylvanian carbonates, paleoecology, and rugose colonial corals, north flank, eastern Brooks Range, arctic Alaska. U.S. Geological Survey Professional Paper, 747, 1-21.

Bamber, E.W., Fedorowski, J., 1998. Biostratigraphy and systematics of Upper Carboniferous cerioid rugose corals, Ellesmere Island, Arctic Canada. Geological Survey of Canada Bulletin, 511, 1-127.

Blodgett, R.B., Boucot, A.J., Rohr, D.M., Pedder, A.E.H., 2010. The Alexander terrane of Alaska - A displaced fragment of northeast Russia: Evidence from Silurian-Middle Devonian megafossils and stratigraphy. Memoir of the Association of Australasian Palaeontologists, 39, 325-341.

Buddington, A.F., Chapin, T., 1929. Geology and mineral deposits of southeastern Alaska. U.S. Geological Survey Bulletin, 800, 398.

Butler, R.F., Gehrels, G.E., Bazard, D.R., 1997. Paleomagnetism of Paleozoic strata of the Alexander terrane, southeastern Alaska. Geological Society of America Bulletin, 109(10), 1372-1388.

Chapman, E.J., 1893. On the corals and coralliform types of Paleozoic strata. Royal Society of Canada Proceedings and Transactions, 10(4), 39-48.

Chwieduk, E., 2013. Palaeogeographical and palaeoecological significance of the uppermost Carboniferous and Permian rugose corals of Spitsbergen. Uniwersytet im. A. Mickiewicza w Poznaniu. Seria Geologia, 23, 1-270.

Colpron, M., Nelson, J.L., 2011. A Palaeozoic NW passage and the Timanian, Caledonian and Uralian connections of some exotic terranes in the North American Cordillera. In: Spencer, A.M., Embry, A.F., Gautier, D.L., Stoupakova, A.V., Sorensen, K. (eds.). Arctic Petroleum Geology. London, Geological Society, 35, 463-484.
Cósar, P., Vachard, D., Somerville, I.D, Medina-Varea, P., Rodríguez, S., Said, I., 2013. The Tindouf Basin, a marine refuge during the Serpukhovian (Carboniferous) mass extinction in the Northwestern Gondwana platform. Palaeogeography, Palaeoclimatology, Palaeoecology, 394, 12-28.

Cotton, G., 1973. The rugose coral genera. Amsterdam, Elsevier, $358 \mathrm{pp}$.

Degtyarev, D.D., 1979. Korally. Coelenterata. In: Einor, O.L. (ed.). Atlas of the fauna and flora of middle-late Carboniferous of Bashkiria. Moskva, Nedra, 41-54.

Dutro, J.T.Jr., Douglass, R.C., 1961. Pennsylvanian rocks in southeastern Alaska. U.S. Geological Survey Professional Paper, 424-B, B239-B241.

Dybowski, W.N., 1873-1874. Monographie der Zoantharia Sclerodermata Rugosa aus der Silurformation Estlands, Nordlivlands und der Insel Gotland. Estlands (Kurlands), Archiv für Naturkunde der Livlands, 1, 257-532.

Fan, Y., Yu, X., He, Y., Pan, Y., Li, X., Wang, F., Tang, D., Chen, S., Zhao, P., Lin, J., 2003. The Late Palaeozoic rugose corals of Xizang (Tibet) and adjacent regions and their palaeobiogeography. National Natural Science Foundation of China, Series of Geoscience, Earth, Hunan Science and Technology Press, 679pp.

Fedorowski, J., 1965. Permian Tetracoralla of Hornsund, Vestspitsbergen. Studia Geologica Polonica, 17, 1-173.

Fedorowski, J., 1967. The Lower Permian Tetracoralla and Tabulata from Treskelodden, Vestspitsbergen. Norsk Polarinstitut Skrifter, 142, 1-41.

Fedorowski, J., 1975. On some Upper Carboniferous Coelenterata from Bjornoya and Spitsbergen. Acta Geologica Polonica, $25,27-78$.

Fedorowski, J., 1978. Some aspects of coloniality in rugose corals. Palaeontology, 21, 177-224.

Fedorowski J., 1981. Carboniferous corals: distribution and sequence. Acta Palaeontologica Polonica, 26, 87-160.

Fedorowski, J., 1997. Remarks on the paleobiology of Rugosa. Geologos, 2, 5-58.

Fedorowski, J., 2004. Considerations on most Rugosa and the Dividocorallia from de Groot (1963) collection. Scripta Geologica, 127, 71-311.

Fedorowski, J., Gorianov, V.B., 1973. Redescription of tetracorals described by E. Eichwald in "Paleontology of Russia". Acta Palaeontologica Polonica, 18, 3-70.

Fedorowski, J., Ogar, V.V., 2013. Early Bashkirian Rugosa (Anthozoa) from the Donetsk Basin,Ukraine. Part 4. Cordibia, a new protocolonial genus. Acta Geologica Polonica, 63(3), 297-314.

Fedorowski, J. Bamber, E.W., Stevens, C.H., 2007. Lower Permian colonial rugose corals, Western and Northwestern Pangaea: Taxonomy and distribution. Ottawa, National Research Council of Canada. National Research Centre Research Press, XII+231pp.

Fedorowski, J., Bamber, E.W., Stevens, C.H., 2014a. A revision of Heritschioides Yabe, 1950 Anthozoa, Rugosa, latest 
Mississippian and earliest Pennsylvanian of western North America. Palaeontologia Electronica, 17(1), 11A, 1-20.

Fedorowski, J., Stevens, C.H., Katvala, E., 2014b. New Late Carboniferous Heritschioidinae (Rugosa) from the Kuiu Island area and Brooks Range, Alaska. Geologica Acta, 12(1), 29-52..

Fleming, J,. 1828. A history of British animals. Edinburgh, Bell and Bredfute. XXIII + $565 \mathrm{p}$.

Flügel, H.W., 1974. Minatoa eine neue Rugosegattung aus der Sadar II-Formation (Bashkirium) Ostirans. Archiv für Lagerstättenforschung in den Ostalpen, 2, 95-107.

Flügel, H.W., 1994. Rugosa aus dem Karbon der Ozbak-KuhGruppe Ost-Irans (2) : Korallen des Sadar II Member. Bashkirium. Jahrbuch der Geologischen Bundesanstalt, 137, 599-616.

Fomichev, V.D., 1953. Rugose corals and stratigraphy of the Middle and Upper Carboniferous and Permian deposits of the Donets Basin. Trudy Vsesoyuznyi Nauchno-Issledovatel'skyi Geologicheskyi Institut (VSEGEI), Gosudarstvennoe Isdatel'stvo Geologicheskoi Literatury, 622pp, with 91p. and 44pls. under separate cover.

Gorsky, I.I., 1951. Carboniferous and Permian corals of Novaya Zemlja (In Russian). Trudy Nauchno-Issledovatel'skovo Instituta Geologii Arktiki, 32, 5-168.

Gorsky, I.I., 1978. Middle Carboniferous corals from the western slope of the Urals. Moscow, Nauka, 223pp.

Groot, G.E.de, 1963. Rugose corals from the Carboniferous of northern Palencia (Spain). Leidse Geologische Mededelingen, 29, 123pp.

Hill, D., 1981. Rugosa and Tabulata. In: Teichert, C. (ed.). Treatise on Invertebrate Paleontology, Part F, Coelenterata. Boulder, Colorado and Lawrence, Kansas. Geological Society of America and University of Kansas Press, Supplement 1, i-xl+F1-F762.

Hudson, R.G.S., 1936. The development and septal notation of the Zoantharia Rugosa (Tetracoralla). Proceedings of the Yorkshire Geological Society, 23, 68-78.

Ivanovsky, A.B., 1976. Index of rugose coral genera. Moscow, Nauka. 255pp.

Ivanovsky, A.B., 1987. Rugosa described by A.A. Stuckenberg (1888-1905). Moscow, Nauka. 44pp.

Kawamura, T., Stevens, C.H., 2012. Middle Pennsylvanian rugose corals from the Baird Formation, Klamath Mountains, northwestern California. Journal of Paleontology, 86, 513520.

Kossovaya, O.L., 1997. Middle and Upper Carboniferous composite zonal sequence based on rugose corals (Western part of Russia). Prace Państwowego Instytutu Geologicznego, 157, Part 3, 85-95.

Kozyreva, T.A., 1973. The new genus Opiphyllum (Rugosa) from the Bashkirian stage of the Voronezh Antiklize. Paleontologicheskii Zhurnal, 3, 129-132.

Kozyreva, T.A., 1978. Novye vidy Srednekamennougolnykh Korallov i filogeniya roda Lonsdaleia (Rugosa). Otdel Geologicheskii, 53(4), 73-81.
Lin, B., Xu, S., Jia, H., Guo, S., Ouyang, X., Wang, Z., Ding, Y., Cao, X., Yan, Y., Chen, H., 1995. Monograph of Palaeozoic corals, Rugosa and Heterocorallia. Beijing, Geological Publishing House, 778pp.

Mamet, B.L., Mason, D., 1970, Lisburne Group, lithostratigraphy and foraminiferal zonation, British Mountains, northern Yukon Territory. Bulletin of Canadian Petroleum Geology, 18(4), 556-565.

Mankinen, E.A., Irwin, W.P., Grommé, C.S., 1989. Paleomagnetic study of the Eastern Klamath terrane, California, and implications for the tectonic history of the Klamath Mountains Province. Journal of Geophysical Research, 94:10,44410,472 .

McCoy, F., 1849. On some new genera and species of Palaeozoic corals and Foraminifera. Annals and Magazine of Natural History, Series 2, 3(13), 1-20, 119-136.

McCutcheon, V.A., Wilson, E.C., 1963. Kleopatrina, new name for Ptolemaia McCutcheon and Wilson. Journal of Paleontology, 37, 299.

Milne Edwards, H.M., Haime, J., 1850-1855. A monograph of the British fossil corals. Palaeontographical Society, 1850, $1-71 ; 1852,147-210 ; 1853,211-244 ; 1855,245-299$.

Minato, M., Kato, M., 1965. Durhaminidae (Tetracoral). Hokkaido University, Faculty of Science Journal, 4, Geology and Mineralogy, 13(1), 13-86.

Muffler, L.J.P., 1967. Stratigraphy of the Keku Islets and neighboring parts of Kuiu and Kupreanof Islands, southeastern Alaska. U.S. Geological Survey Bulletin, 1241-C, C1-C52.

Rodríguez, S., 1984. Corales Rugosos del Carbonifero del Este de Asturias. Doctoral Thesis. Madrid, Department of Paleontology, Universidad Complutense de Madrid, collection 109/84, 528pp, 32pls.

Rodríguez, S., Somerville, I.D., 2010. Appearance of fasciculate rugose corals in the Viséan and Serpukhovian: A review. Palaeoworld, 19, 306-315.

Sando, W.J., 1983. Revision of Lithostrotionella (Coelenterata, Rugosa) from the Carboniferous and Permian. Geological Survey, Professional Paper, 1247, 1-52.

Sando, W.J., 1985. Paraheritschioides, a new rugose coral genus from the Upper Pennsylvanian of Idaho. Journal of Paleontology, 59, 979-985.

Smith, S., Ryder, T.A., 1926. The genus Corwenia gen. nov. The Annals and Magazine of Natural History, 27, 149-159.

Somerville, I., 1997. Biostratigraphy and biofacies of Upper Carboniferous-Lower Permian coral assemblages from the Isfjorden area, Central Spitsbergen. Real Sociedad Española de Historia Natural. Sección Geólogica, Boletin 93, 365-380.

Spasskiy, N.Y., Kachanov, E.I., 1971. Novye primitivnye rannekamennougolnye korally Altaya i Urala. Zapiski Leningradskogo Gornogo Instituta, 59, 48-64.

Stevens, C.H., Rycerski, B., 1989. Early Permian colonial rugose corals from the Stikine River area, British Columbia, Canada. Journal of Paleontology, 63, 158-181.

Stuckenberg, A.A., 1904. Corals and bryozoans from the lower division of the central Russian Carboniferous limestone. 
Trudy Geologicheskago Komiteta, Novaya seriya, 14, I-IV, 1-109, pls. 1-9.

Sutherland, P.K., 1965. Henryhouse rugose corals. Oklahoma Geological Survey, 109, 1-92.

Vassilyuk, N.P., 1974. Development of corals at the early and middle Carboniferous boundary. Paleontologicheskiy Zhurnal, 4, 3-10.

Verrill, A.E., 1865. Classification of polyps (Extract condensed from a synopsis of the polypi of the North Pacific Exploring Expedition, under captains Ringgold and Rodgers, U.S.N.). Proceedings of the Essex Institute, 4, 145-149.

Wilson, E.C., 1982. Wolfcampian rugose and tabulate corals (Coelenterata: Anthozoa) from the Lower Permian McCloud
Limestone of northern California. Natural History Museum of Los Angeles County, Contributions in Science, 337, 90pp. Wu, W., Zhao, J., 1989. Carboniferous and early Early Permian Rugosa from Western Guizhou and Eastern Yunan, southwestern China. Palaeontologia Sinica, 177, New Series B, 24, 230pp, 63pls.

Wu, W., Zhou, K., 1982. Upper Carboniferous corals from Kapling and Aksu, Xinjiang. Nanjijng Institute of Geology and Palaeontology, Academia Sinica, 4, 213-239.

Yabe, H., 1950. Permian corals resembling Waagenophyllum and Corwenia. Proceedings of the Japanese Academy, 26, 74-79.

Manuscript received January 2014;

revision accepted July 2014;

published Online July 2014. 


\section{APPENDIX I}

USGS 4305-PC. Petersburg 1:4 quadrangle, Kuiu Island, west of south end of Keku Island Group. Limestone interbedded with basaltic lava. The limestones are rich in corals identified as Lonsdaleia and Clisiophyllum by Buddington and Chapin (1929), both taxa need revision. These fossils apparently are from the Volcanic member of the Saginaw Bay Fm. of Muffler (1967). Species of the conodont genus Idiognathoides of probable Moscovian age occur near the coral locality. Collected by A.F. Buddington, 1922 (see Buddington and Chapin, 1929) from rocks called the "Lower Division of the Permian".

USGS 27727-PC (63Amp 590, map loc. 85 of Muffler, 1967). Southwest shore of islet 0.2 mile northeast of northeast shore of Kuiu Island, lat. 56 $55.74^{\prime} \mathrm{N}$, long. $134^{\circ} 12.39^{\prime} \mathrm{W}$. Massive crinoidal limestone in crinoidal limestone unit. Brachiopods were considered Morrowan by Dutro and Douglas (1961). Conodonts from strata close to the coral locality include species of Idiognathoides and Neognathodus of Bashkirian age. Collected by Muffler, 1965 (see Muffler, 1967).

FH-C-F2, Floating Hatchery, Keku Strait Region, south end of Cornwallis Peninsula on the northeast shore of Kuiu Island, mapped as Volcanic Member of the Saginaw Bay Fm. by Muffler (1967). This locality is northwest of a small, narrow inlet at the southern end of this unit as mapped by Muffler (1967). A floating hatchery is located in this inlet. Conodonts from near the coral locality contain Moscovian species of Idiognathoides. Collected by Erik Katvala in 2005. USGS locality 4305-PC also is from this general area. 